\title{
Dinî Uzlaşma Kültürü Bağlamında İlahiyat Eğitimi*
}

\section{Theology Education in Terms of Religious Reconciliation Culture}

\author{
Şeyma Turan ** $\odot$, Bayramali Nazıroğlu"
}

Öz

Illahiyat eğitiminin dinîuzlaşma kültürüne etkisinin ele alındığı bu araştırmada, esas olarak öğrencilerin konuyla ilgili düşünce ve yaklaşımlarına odaklanılmıştır. Araştırmada öğrencilerin dinî uzlaşma kültürü hakkındaki görüşlerinin tespit edilmesi için nitel araştırma yöntemleri kullanılmıştr. Dinî uzlaşma kültürü ile ilgili teorik verilerin doküman analizi yöntemiyle incelenmesi sonucunda araştırmanın ana temaları uzlaşma, çatş̧ma, öteki, empati ve iletişim olarak belirlenmiştir. Metin içinde bu temalar, öğrencilerin bu kavramlar hakkındaki görüşlerinin okuyucu tarafindan daha iyi anlaşılabilmesi amacıyla öteki, çatş̧ma, empati-iletişim ve uzlaşma şeklinde sıralanmıştr. Öğrencilerin konu hakkındaki görüşlerine ilişkin veriler, araştırmacılar tarafindan hazırlanan yarı yapılandırılmış görüşme formuyla elde edilmiştir. Bu doğrultuda çalışma grubu olarak seçilen Recep Tayyip Erdoğan Üniversitesi Illahiyat Fakültesinden 2018-2019 öğretim yılında mezun olan 27 son sınıf öğrencisiyle görüşmeler yapılmıştı. Öğrencilerden elde edilen veriler, betimsel analiz ve içerik analizi yöntemleriyle dört ana tema içerisinde değerlendirilmiştir. Araştırma sonucunda öğrencilerin büyük bir kısmının aldıkları eğitimin potansiyel olarak ötekileştirme ve çațşmaya neden olabileceğine inandıkları; buna karşın ilahiyat eğitiminin hem empati ve iletişim kurmaya hem de dinî uzlaşma kültürü oluşturmaya katkı sağladığını düşündükleri tespit edilmiştir. Ayrıca öğrencilerin zihinlerinde öteki, çaţşma, empati ve uzlaşma kavramlarının tam karşılığının olmadığı ve bu temalara ilişkin değerlendirme yaparken parçacı bir yaklaşım benimsedikleri de görülmüştür.

Anahtar Kelimeler

İlahiyat eğitimi, Dinî uzlaşma kültürü, Çatışma, Öteki, Empati/iletişim

\begin{abstract}
This research addresses the effect of theology education on religious reconciliation culture and focuses on the views of students about the subject. In the research, qualitative methods were used because students' views on the topic were presented. The theoretical data on the religious reconciliation culture was examined by using the document analysis method; the themes of the study were reconciliation, conflict, other, empathy, and communication. The students' views on this issue were obtained by using a semistructured interview form prepared by the researcher. Interviews were conducted with 27 senior students who graduated from the Faculty of Theology of Recep Tayyip Erdoğan University, the study group, in the 2018-2019 academic year. Data obtained from the students were evaluated in the four main themes by using descriptive analysis and content analysis. The results demonstrated that although the majority of the students believed that the education they received could potentially cause othering and conflict; they think that this education contributes to both empathy-communication and establishing a religious reconciliation culture.
\end{abstract}

\section{Keywords}

Theology education, Religious reconciliation culture, Conflict, Other, Empathy/communication

* Bu makale, Doç. Dr. Bayramali Nazıroğlu danışmanlığında Şeyma Turan tarafindan hazırlanan “Yüksek Din Öğretiminin Öğrencilerin Dinî Uzlaşma Kültürlerine Etkisi -RTEÜ ilahiyat Fakültesi Örneği-" isimli yüksek lisans tezinden hareketle hazırlanmışttr.

** Sorumlu Yazar: Şeyma Turan (Arş. Gör.), Recep Tayyip Erdoğan Üniversitesi, İlahiyat Fakültesi, Din Eğitimi Anabilim Dalı, Rize, Türkiye. E-posta: seyma.turan@erdogan.edu.tr ORCID: 0000-0001-9398-5053

*** Bayramali Nazıroğlu (Doç. Dr.), Recep Tayyip Erdoğan Üniversitesi, illahiyat Fakültesi, Din Eğitimi Anabilim Dalı, Rize, Türkiye. E-posta: bayramali.naziroglu@erdogan.edu.tr ORCID: 0000-0003- 2091-614X

Atıf: Şeyma Turan, Bayramali Nazıroğlu “Dinî Uzlaşma Kültürü Bağlamında ilahiyat Eğitimi.” darulfunun ilahiyat 32, 1 (2021): $219-256$. https://doi.org/10.26650/di.2021.32.1.845950 


\section{Extended Summary}

Emotions, thoughts, attitudes, and beliefs are the main indicators of diversity among human beings. However, individuals occasionally believe that their personal preferences are the absolute truth. Therefore, the differences in opinions on religion cause conflicts among individuals and societies. Cognitive transformation is necessary in many areas to foster human nature from conflict to reconciliation. Education is at the forefront of these areas. Along with many other components of the Turkish education system, theology education aims to realize similar objectives. Consequently, students who study theology are also expected to have a reconciliatory approach to religious differences. Thus, the main research question of this paper is as follows: "What is the effect of theology education on students' religious reconciliation culture?" This study contributes to the literature in that it is the first to examine the effect of theology education on students' approach to differences inside religion.

This study aims to examine the effect of theology education on religious reconciliation culture in depth. Therefore, the qualitative method was used. In addition, a phenomenological pattern, case pattern, and culture analysis pattern were used.

The research population comprises senior students who study at the Faculty of Theology at Recep Tayyip Erdogan University in the 2018-2019 academic year. Maximum variation sampling and snowball sampling methods were used to determine the study group. Interviews were conducted with 27 students. The information on the sample is in Table 1.

\section{Table 1.}

Basic Data of the Sample

\begin{tabular}{|c|l|c|c|}
\hline \multirow{2}{*}{ Gender } & Female & 14 & \multirow{2}{*}{$\begin{array}{c}\text { Total } \\
27\end{array}$} \\
\cline { 2 - 3 } & Male & 13 & 27 \\
\hline \multirow{2}{*}{ Curriculum } & Theology Education & 14 \\
\cline { 2 - 3 } & Theology Second Education (Evening Education) & 13 & \\
\hline \multirow{2}{*}{$\begin{array}{c}\text { High School } \\
\text { Graduated }\end{array}$} & Imam Hatip High School & 21 & \multirow{2}{*}{27} \\
\cline { 2 - 3 } & High School & 6 & \\
\hline
\end{tabular}

In the research, a literature review and interview were used as data collection techniques. During the interviews, a semistructured interview form comprising 23 questions prepared by the researchers was used. Interviews were conducted with volunteer students between December 27, 2018, and March 21, 2019. All students signed the consent form before the interview started. The data collected in the literature review were analyzed by using the document analysis method. During the analysis of student views, descriptive analysis and content analysis techniques were used. To prevent exceeding the limits of this study, the researchers used the data obtained from student interviews at a minimum level. 
Student views were grouped under four themes: the other, conflict, empathycommunication, and reconciliation. In this context, the students stated that theology education, on the one hand, caused othering and conflict and, on the other hand, improved their empathy, communication, and reconciliation skills. The students also stated that some of their friends had negative views on the other and conflict; however, they emphasized that they had a positive attitude toward empathy and reconciliation.

Notably, the students' views on the courses mostly focused on the fields of Basic Islamic Sciences (BIS) and Philosophy and Religious Sciences (PRS), and they made few references to the field of Islamic History and Art. Differences were also observed in student views on BIS. The main reason for this situation is that the students conduct their evaluation on the BIS lessons such as hadith, kalam, and Islamic law by considering their lecturers' attitudes and religious views. The students stated that lecturers to whom they feel close contributed to their developing empathy and reconciliation and did not cause othering and conflict.

Regarding the PRS lessons and pedagogical formation courses, the research results differ. Most of the students think that the courses in the PRS field contribute to communication, empathy and reconciliation. Moreover, students had a common opinion on this issue while considering both the lessons and the lecturers' impact.

In summary, student views on some points are contradictory. This study demonstrated that students do not attach specific meanings to the concepts of the other, conflict, empathy, and reconciliation while evaluating them. In addition, the students made general inferences based on single examples. In summary, students do not develop a holistic perspective of theological education in terms of reconciliation, conflict, empathy, and communication. 


\section{Giriş}

İnsanlar arasında birlik, beraberlik ve dayanışmanın sağlanması ve ahenkli bir toplumun oluşması için hayatın her alanında uzlaşmanın esas alınması ve barış ortamının tesis edilmesi gerekir. Bu doğrultuda İslam dininin temel kaynağı olan Kur'an-1 Kerim'de insanların, özellikle de Müslümanların birlik-beraberlik, ${ }^{1}$ kardeşlik, ${ }^{2}$ uzlaşma ${ }^{3}$ ve barışş içinde yaşamalarını telkin eden pek çok işaret vardır. Her ne kadar İslam'da belli şartlar altında çatışma ve savaşlara meşruiyet atfedilse ${ }^{5}$ de ana ilke olarak sorunların barış yoluyla halledilmesi esastır. Nitekim Hz. Peygamber de yaşadığı toplumda çatışma yerine birlik ve beraberliğin sağlanması için gayret göstermiştir. ${ }^{6}$ Bu durum, hem diğer din mensuplarıyla kurulan ilişkilerde hem de Müslümanlar arası ilişkilerde geçerli temel bir ilke olmuştur.

Buna karşın Hz. Peygamberin vefatının akabinde başlayan, çoğu kişisel hırs ve beklentiden, politik farklılıktan ve kabile taassubundan kaynaklanan anlaşmazlıklar, zamanla Müslümanlar arasında gerilim ve çatışmalara yol açmıştır. Bu gerilim ve çatışmalar, kimi zaman sadece salt anlaşmazlık boyutunda kalmış kimi zaman ise felaket ve ölümlerle sonuçlanan şiddet ve savaşlara ${ }^{7}$ evrilmiştir. Bu olaylar neticesinde İslam dünyasında ilk dinî kopuşlar ${ }^{8}$ başlamış; böylece çeşitli mezhep ve dinî görüşler ortaya çıkmıştır. Bunların zuhuru, bizatihi problem teşkil etmese de her birinin diğerine karşı genelde dışlayıc ${ }^{9}$ bir tavır benimsemesi, İslam dünyasındaki bölünmeleri derinleştirmiştir. Zamanla bu tefrikayı ortadan kaldıracak bazı cılız girişimler olmuşsa $\mathrm{da}^{10}$ Müslüman toplumlar bir daha tam anlamıyla birlik ve beraberlik yüzü görmemiştir.

1 Enfâl 8/46.

2 Hucurât 49/10.

3 Enfâl 8/62.

4 Enfâl 8/61; Hucurât 49/9; Mümtehine 60/8-9.

5 Bakara 2/190; Tevbe 9/12.

6 Hz. Peygamberin toplumsal birliği sağlamak için hem Mekke'de hem de Medine'de Müslümanlara uyguladığı kardeşleştirme uygulaması için bkz. İbrahim Sarıçam, Hz. Muhammed ve Evrensel Mesajı (Ankara: Diyanet İşleri Başkanlığı Yayınları, 2011), 139-142.

7 Müslümanlar arasında yaşanan ve mezheplerin ortaya çıkmasında belirleyici olan ilk iç savaşlar Cemel ve Siffın Savaşı ve Tahkim Olayı için bkz. Âdem Apak, Ana Hatlarıyla İslam Eğitim Tarihi 2 (Hulefầ-i Râşidîn Dönemi) (İstanbul: Ensar Neşriyat, 2013), 266-315.

8 İlk dinî kopuş olan Hariciliğin doğuşu ve gelişme süreciyle ilgili bkz. Mustafa Öz, Başlangıçtan Günümüze İslâm Mezhepleri Tarihi (İstanbul: Ensar Neşriyat, 2016), 84-91.

9 Mahmut Aydın, "Paradigmanın Yeni Adı: Dinsel Çoğulculuk”, içinde Hıristiyan, Yahudi ve Müslüman Perspektifinden Dinsel Çoğulculuk ve Mutlaklık İddiaları, ed. Mahmut Aydın (Ankara: Ankara Okulu Yayınları, 2005), 26-30.

10 Sünni-Şii ittifak girişimi için bkz. Bekir Topaloğlu, Kelam Illmine Girişs (İstanbul: Damla Yayınevi, 2014), 317-46. 
İnsanların duygu, düşünce, tutum ve inanç gibi konularda farklı fikirlere sahip olmaları doğaldır. Ancak bazı insanlar, kendi tercihlerinin mutlak hakikat olduğuna inandığ 1 için özellikle dinî konularda ortaya çıkan fikir ayrılıkları hem bireyler hem de toplumlar arasında zaman zaman gerilimlere ve buna bağlı çatışmalara yol açmaktadır. Bu çatışmaları ortadan kaldırmak ya da en azından makul düzeye indirmek için eğitim kurumlarına düşen bazı sorumluluklar vardır. Bu bağlamda dünyadaki pek çok eğitim sisteminde olduğu gibi Türk eğitim sisteminde de öğrencilerin dengeli ve sağlıklı bir karaktere, hür ve bilimsel düşünme gücüne, geniş bir dünya görüşüne sahip olmaları; insan haklarına duyarlı hareket etmeleri ve topluma karşı sorumlu davranmaları üzerinde durulmaktadır. ${ }^{11} \mathrm{Bu}$ temel yaklaşım doğrultusunda ilahiyat ${ }^{12}$ eğitiminde de benzer amaçlara yer verilmektedir.

İlahiyat programının öğrenme çıktıları arasında ideolojilerin ötesinde bir bakış açısına sahip olma, güncel meselelere çözüm bulma, mevcut dinî bilgileri denetleme, güncelleme ve yenileme vb. ifadelerin ${ }^{13}$ bulunması, öğrencilerin farklı dinî görüşlere daha açık olmasına firsat tanımaktadır. Böylece bahsedilen öğrenme çıktılarını elde eden öğrencilerin dinî farklılıklar konusunda çatışmadan ziyade, uzlaşmacı bir yaklaşıma sahip olması beklenir. Ancak bunun gerçekleşip gerçekleşmediğini öğrenmek için farklı yöntemlerle alan araştırmalarının yapılması gerekir. Bu

11 Milli Eğitim Temel Kanunu (METK), Resmi Gazete 14574 (24 Haziran 1973), Kanun No. 1739, md. 2,3 .

12 İlahiyat sözcüğü bu çalışmada aksi belirtilmediği sürece tüm yüksek din öğretimi kurumlarını temsilen kullanılmıştır.

13 Bkz. Muhammet Şevki Aydın, "İlahiyat Lisans Programının Amaç Sorunu” (Türkiye'de Yüksek Din Eğitiminin Sorunları, Yeniden Yapılanması ve Geleceği Sempozyumu Bildiriler-Müzakereler (16-17 Ekim 2003), Isparta: SDÜ İlahiyat Fakültesi Yayınları, 2004), 19-25; Nevzat Yaşar Aşıkoğlu, "İlahiyat Fakültelerinin Eğitim Öğretime Katkıları ve Kaliteye Yolculuk”, Cumhuriyet Üniversitesi İlahiyat Fakültesi Dergisi 9, sy 1 (2005): 5-6; Mustafa Öztürk, “İlahiyat’ın Ad1 ve Amaçları”, içinde Bugünün İlahiyatı Nasıl Olmalıdır? Sorunlar ve Çözümleri (İstanbul: Ensar Neşriyat, 2015), 57; Recai Doğan, "İlahiyat Fakültelerinin Eğitim Anlayışı Nasıl Olmalıdır?” (Bugünün İlahiyatı Nasıl Olmalıdır? Olmalıdır?-Sorunlar ve Çözümler- (01-04 Haziran 2014), İstanbul: Ensar Neşriyat, 2015), 362-68; Nevzat Yaşar Aşıkoğlu, "Yükseköğretimde Din Eğitimi ve Öğretimi”, içinde Din Eğitimi, ed. Recai Doğan ve Remziye Ege (Ankara: Grafiker Yayınları, 2016), 190-92; Halit Ev, "Yükseköğretimde Din Eğitimi”, içinde Din Eğitimi, ed. Mustafa Köylü ve Nurullah Altaş (İstanbul: Ensar Neşriyat, 2016), 290-95; İbrahim Turan, “Türkiye'de İlahiyat Eğitimi: İstihdam Alanı-Program İlişkisi Üzerine Bir İlişki”, İstanbul Üniversitesi İlahiyat Fakültesi Dergisi, sy 37 (2017): 63-68; Muhammet Şevki Aydın, Din Eğitimi Bilimi (Kayseri: Kimlik Yayınevi, 2017), 209-13; Muhammed Ali Yazıbaşı "Yükseköğretimde Din Eğitimi”, içinde Din Ĕ̆itimi, ed. Hasan Dam (İstanbul: Lisans Yayıncılık, 2018), 166; Bayramali Nazıroğlu, Derdimiz İlahiyat-Akademisyenlerinin Gözünden İçe Kritik Bakış- (İstanbul: Okur Akademi, 2020); Yüksek din öğretiminin amaçlarına uygun olarak yeniden yapılandırılması için bkz. Ramazan Buyrukçu, “İlahiyat Fakültelerinin Yeniden Yapılandırılması Problemi” (Türkiye’de Yüksek Din Eğitiminin Sorunları, Yeniden Yapılanması ve Geleceği Sempozyumu Bildiriler-Müzakereler (16-17 Ekim 2003 Isparta), Isparta: SDÜ İlahiyat Fakültesi Yayınları, 2004), 509-20. 
çalışma da böyle bir ihtiyaca cevap üretmek için yapılmış ve araştırma süresince “İlahiyat eğitiminin öğrencilerin dinî uzlaşma kültürüne etkisi nedir?” sorusunun cevabı aranmıştır.

Dinî uzlaşma kültürü, en yalın haliyle aynı dine inanan bireylerin bir arada yaşaması şeklinde tanımlanabilir. Söz gelimi, dinî uzlaşma kültürüyle Müslüman olan, ancak farklı dinî görüşlere sahip bireylerin birlikte yaşaması kast edilir. Buradan hareketle dinî uzlaşma kültürü birlikte yaşama kavramının kapsamı içinde değerlendirilebilir. Fakat literatür incelendiğinde birlikte yaşama konusunun, genellikle farklı din mensupları üzerinden ele alındığı görülmektedir. ${ }^{14} \mathrm{Bu}$ nedenle literatürde dinî uzlaşma kültürü ile birlikte yaşama kültürünün belirgin bir şekilde birbirlerinden ayrı bağlamlarda ele alındığını akılda tutmak gerekir.

\section{Dinî Uzlaşma Anlayışı ve Kültürüi}

Felsefe, sosyoloji, psikoloji ve eğitim gibi pek çok alanda ele alınan uzlaşma kavramı; karşılıklı ödünlerde bulunarak anlaşmaya varma, ${ }^{15}$ kişilerarası çatışmaları ortadan kaldırma, ${ }^{16}$ toplumsal uyum süreci ${ }^{17}$ gibi çeşitli anlamlarda kullanılmaktadır. Dökmen ${ }^{18}$ uzlaşmayı “...insanın kendi içindeki ve çevresi ile kendi arasındaki sorunları, çatışmaları, kendisinin ve ilgili diğer kişilerin/şeylerin çıkarlarını gözeterek çözmesi..." şeklinde tanımlamaktadır. Buna karşın Aronson, Wilson ve Akert, ${ }^{19}$ uzlaşmanın sosyal yönünü ön plana çıkarmakta ve kişiler arası ilişkiler bağlamında uzlaşmay1; "çatışma halindeki karşıt tarafların teklifler ve karşıt teklifler sunduğu ve her iki tarafın da anlaşması durumunda bir çözüme ulaşıldığı bir iletişim biçimi”" olarak ele almaktadırlar. Margalit ise bir anlaşmanın uzlaşma olabilmesi için iki tarafın da karşılıklı tavizlerde bulunmasını gerekli görmekte ${ }^{20}$ ve sıhhatli uzlaşmanın

14 Örnek olarak bkz. Mehmet Nuri Y1lmaz, "İslâm ve Dinler Arası Birlikte Yaşama”, Diyanet İlmi Dergi 34, sy 2 (1998): 3-20; Abdurrahman Güneş, "Toplumsal Bir Zorunluluk: Bir Arada Yaşamak", Firat Üniversitesi İlahiyat Fakültesi Dergisi 10, sy 2 (2005): 89-103; Nebi Gümüş, “Osmanlı'da Birlikte Yaşama Tecrübesi: Ermeniler Örneği”, Milel ve Nihal: İnanç, Kültür ve Mitoloji Araştırmaları Dergisi 6, sy 2 (2009): 165-98.

15 TDK, “Uzlaşma”, içinde Türkçe Sözlük (Ankara: Türk Dil Kurumu Yayınları, 2011), 2437.

16 Remzi Öncül, “Uzlaşma”, Eğitim ve Eğitim Bilimleri Sözlüğü (İstanbul: Milli Eğitim Bakanlığ1 Yayınları, 2000), 118.

17 Rasim Bakırcıŏlu, “Uyum II”, içinde Ansiklopedik Eğitim ve Psikoloji Sözlüğü (Ankara: Anı Yayınc1lik, 2012), 945-46.

18 Üstün Dökmen, Evrenle Uyumlaşma Sürecinde Varolmak, Gelişmek, Uzlaşmak (İstanbul: Remzi Kitabevi, 2017), 266.

19 Elliot Aronson, Timothy D. Wilson, ve Robin M. Akert, Sosyal Psikoloji, çev. Okhan Gündüz (İstanbul: Kaknüs Yayınları, 2012), 548-49.

20 Avishai Margalit, Uzlaşma ve Kokuşmuş Uzlaşmalar, çev. Nedim Çatlı (İstanbul: İthaki Yayınları, 2013), 24. 
özelliklerini karşılıklı ödün verme, müzakere etme, müzakere çıkmazını aşma ve taraflardan birinin diğerine zorlama uygulamamas $1^{21}$ olarak sıralamaktadır.

Tanımlarda ifade edildiği gibi bir uzlaşma ortamının oluşması için var olmak, ${ }^{22}$ gelişmek, ${ }^{23}$ kendini tanımak, ${ }^{24}$ müzakere etmek, ${ }^{25}$ yaratıcılık, ${ }^{26}$ iletişim kurmak ${ }^{27}$ ve toplumsal bütünleşme ${ }^{28}$ gibi birtakım unsurlar iç içe bulunmalı ve bu unsurlar birbirini desteklemelidir. Uzlaşma, kuşkusuz bireyde başlayan bir süreçtir. $\mathrm{Bu}$ sürecin sağlıklı yürümesi için kişinin kendini tanıması ve kendiyle sağlıklı bir iletişim kurmasıyla varoluşunu mümkün olduğunca üst düzeyde gerçekleştirmesi gerekir. Kendiyle uzlaşan bireyin böylece çevresiyle ve toplumla uzlaşması da mümkün hâle gelir.

Uzlaşmanın karşıtı olan çatışma, tıpkı uzlaşma gibi hem bireyin iç dünyasında hem de kişiler arası ilişkilerde tezahür eder. Literatürde çatışma; fikir ayrılığı, anlaşmazlık, ${ }^{29}$ karşı tarafın çıkarlarını zarara uğratma, ${ }^{30}$ bireyin iç dünyasında meydana gelen iki karşıt duygunun, düşüncenin aynı anda ortaya çıkması, ${ }^{31}$ sağlısıı

21 Margalit, 54-61.

22 Dökmen, Evrenle Uyumlaşma Sürecinde Varolmak, Gelişmek, Uzlaşmak, 270.

23 Dökmen, 271.

24 Dökmen, 271-72; Çiğdem Kağıtçıbaşı ve Zeynep Cemalcılar, Dünden Bugüne İnsan ve İnsanlar Sosyal Psikolojiye Giriş (İstanbul: Evrim Yayınevi, 2018), 248.

25 Margalit, Uzlaşma ve Kokuşmuş Uzlaşmalar, 57-61; Dökmen, Evrenle Uyumlaşma Sürecinde Varolmak, Gelişmek, Uzlaşmak, 272.

26 Dökmen, Evrenle Uyumlaşma Sürecinde Varolmak, Gelişmek, Uzlaşmak, 244.

27 Aronson, Wilson, ve Akert, Sosyal Psikoloji, 550-51; bkz. Üstün Dökmen, İletişim Çatışmaları ve Empati (İstanbul: Remzi Kitabevi, 2018), 38-63; Uzlaşma için gerekli sağlıklı iletişsimin dört temel unsuru ve bu temel unsurlarla ilgili çeşitli özellikler hakkında detaylı bilgi için bkz. Kağıtçıbaşı ve Cemalcılar, Dünden Bugüne İnsan ve İnsanlar Sosyal Psikolojiye Giriş, 186-217.

28 Aydın Yaka, Sosyoloji Yazıları Çatışma Kültüründen Uzlaşma Kültürüne (İstanbul: Gündoğan Yayınlar1, 2018), 368-73.

29 Nuri Bilgin, "Çatışma”, içinde Sosyal Psikoloji Sözlügü Kavramlar, Yaklaşımlar (İstanbul: Bağlam Yayıncılık, 2016), 73.

30 Remzi Öncül, "Çatışma”, içinde Eğitim ve Eğitim Bilimleri Sözlüğü (İstanbul: Milli Eğitim Bakanlığı Yayınları, 2000), 229-30; Ayrıca bkz. M. Çetin Gülovalı ve Ayşenur Odabaş, "Çatışma", içinde Türkçe Bilim Terimleri Sözlügü Sosyal Bilimler (Ankara: Türkiye Sosyal Bilimler Akademisi, 2011), 233-34.

31 Detaylı bilgi için bkz. Mehmet Murat Dögüşgen, "Çatışma”, içinde Psikoloji Psikiyatri Sözlüğü (İstanbul: Emre Yayınları, 2005), 58; Güncel Masaloğulları ve Muhammet Koçakgöl, "Çatışma", içinde Psikoloji Sözlüğ̈̈ (Ankara: Nobel Akademik Yayınc1lık, 2011), 38; Doğan Cüceloğlu, İnsan ve Davranışı (İstanbul: Remzi Kitabevi, 2017), 281-82; O. A. Gürün, "Çatışma”, içinde Psikoloji Sözlüğ̈̈ (İstanbul: İnk1lap Kitabevi, t.y.), 29. 
iletişim kurma ${ }^{32}$ gibi anlamlarda kullanılmaktadır. Karşılıklı ilişkilerde uzlaşmanın mı yoksa çatışmanın $m ı$ egemen olacağını bireyin muhatabına bakış açısı tayin eder. Burada belirleyici olan husus, ötekine yüklenen anlamdır. Zira genelde olumsuz bir çağrışımı olan öteki kavramı, aslında hem bireyin kendini tanımas $1^{33}$ hem de muhatabını anlamas ${ }^{34}$ noktasında olumlu bir işleve de sahip olmakta ve bu haliyle uzlaşmaya fırsat sunmaktadır. Nitekim Margalit ${ }^{35}$ de sıhhatli bir uzlaşma ortamının oluşması için ötekini tanımanın önemine değinmektedir. Bununla birlikte ötekine karşı dışlayıcı bir üslup takınılırsa, çatışma hâli meydana gelir. Bu bağlamda hem uzlaşma ortamının oluşabilmesi hem de ötekine iyimser bakılabilmesi için önemli olan faktörlerden biri olarak empati yeteneğine ihtiyaç duyulur. Çünkü empati, bireyin karşısındaki insanı anlamasına, onun anlam dünyasına girmesine ${ }^{36}$ kendini onun yerine koymasına, ${ }^{37}$ bütünü görmeyi sağlamasına olanak tanır. Tarhan da, ${ }^{38}$ empatinin dogmaların ve önyargıların kaldırılmasında önemli bir rol oynadığının altını çizer. Buradan hareketle empati duygusu gelişmiş bireyin ötekine yaklaşımının çatışmadan ziyade uzlaşma kültürü çerçevesinde şekillenmesinin daha muhtemel bir sonuç olduğu söylenebilir.

Konuya din açısından yaklaşıldığında, onun uzlaşmaya katkı sağlama potansiyelinin tartışmalı olduğu görülür. Örneğin Furseth ve Repstad, ${ }^{39}$ dinin sosyal bütünleşmeyi sağlayan kurumlar arasında olduğunu belirtirken; Aydın ${ }^{40}$ ve Sinanoğlu ${ }^{41}$ dinlerin farklılıkları tolere etme noktasında zorlandığının altını

32 Dökmen, İletişim Çatışmaları ve Empati, 38-39.

33 Güçlü v.dğr., "Öteki”, 1102-1104.

34 Dökmen, Evrenle Uyumlaşma Sürecinde Varolmak, Gelişmek, Uzlaşmak, 77-80; 83-84.

35 Margalit, Uzlaşma ve Kokuşmuş Uzlaşmalar, 47.

36 Carl R. Rogers, "Empatik Olmak, Değeri Anlaşılmamış Bir Varoluş Şeklidir”, çev. Füsun Akkoyun, Ankara Üniversitesi Ĕgitim Bilimleri Fakültesi Dergisi 16, sy 1 (1983): 107-8.

37 Mehmet Murat Döğüşgen, “Empati”, içinde Psikoloji Psikiyatri Sözlüğü (İstanbul: Emre Yayınları, 2005), 79; Halil Apaydın, “Empati”, içinde Din Psikolojisi Terimler Sözlüğü (İstanbul: Bilimkent Yayınları, 2016), 92-93; bkz. Dökmen, Illetişim Çatışmaları ve Empati, 157-59; Dökmen ve Apaydın'ın tanımlamalarına benzer ifadelere felsefe sözlügünde de rastmaktadır. Detaylı bilgi için bkz. Ahmet Cevizci, "Empati”, içinde Felsefe Sözlüğü (İstanbul: Paradigma Yayınları, 2002), 351-52; Empati kavramının üç sacayağ 1 ve ortak özellikleri ile ilgili olarak bkz. Yusuf Batar, Empatik Din Eğitimi (İstanbul: Elips Kitap, 2011), 30-36.

38 Nevzat Tarhan, Toplum Psikolojisi ve Empati Sosyal Şizofreniden Toplumsal Empatiye (İstanbul: Timaş Yayınları, 2017), 79.

39 Inger Furseth ve Pal Repstad, Din Sosyolojisine Giriş Klasik ve Çağdaş Kuramlar, çev. İhsan Çapçıŏlu ve Halil Aydınalp (Ankara: Birleşik Yayınevi, 2011), 268.

40 Mustafa Aydın, Sistematik Din Sosyolojisi (İstanbul: Açılım Kitap, 2014), 54-55.

41 Sinanoğlu, "Evrensel Düzeyde Uzlaşı ve Hoşgörü Kültürünün İmkânı”, 32-33. 
çizmektedirler. Sinanoğlu, ayrıca mezhep ve ekollerin de benzer zorluklarla karş1 karşıya olduğunu vurgulamaktadır. Sünni İslam üzerinden meseleye yaklaşan Lakitsch $^{42}$ de Suriye'de yaşanan olayları merkeze alarak benzer zorluğa dikkat çekmektedir.

Dinî çatışmaların nedenleri arasında bireysel ya da kurumsal sekülerleşme olgusu, otoritenin kaynağının beşeri ya da ilahi olması tartışmaları ${ }^{43}$ dinî kaynakların ihtilafa müsait yapısı, dindarların siyasal ve kültürel tecrübeleri, dinî gruplaşma, ${ }^{44}$ fanatizm, ${ }^{45}$ münazara geleneğ ${ }^{46}$ sayılabilir. Bunlara karşın İnan ${ }^{47}$ Kur'an-1 Kerim'de uzlaşmanın merkezde olduğunu ve savaş konseptinin araçsallık ifade ettiğini belirtmektedir. Nitekim Yılmaz ${ }^{48}$ ve Yeşilyurt ${ }^{49}$ da dinlerin özünde kuşatıcı olduğuna dikkat çekerken, anlayış farklılıklarının çatışmaya sebebiyet verdiğini vurgulamaktadırlar.

Dinle ilgili meselelerde çatışmanın yerine uzlaşmanın hâkim olması için temel şartlardan biri, bireylerin dinî uzlaşma anlayışına sahip olmalarıdır. Dinî uzlaşma anlayışı; dinî konularda bireyin önce kendini tanıması yani kendi inancı noktasında bilinçlenmesi ve varoluşsal aşamaları tamamlaması; ardından dinî mevzularda kendinden farklı düşünen muhataplarını yargılamadan dinlemesi, sağlıklı iletişim ve empati kurması, anlam dünyasını genişletmesi ve farklılıklara açık hâle gelmesiyle oluşan bireysel anlayış tarzıdır. ${ }^{50} \mathrm{Bu}$ doğrultuda dinî uzlaşma kültürü de dinî uzlaşma anlayışının belli bir ortamda ya da zamanda baskın hâle gelmesi şeklinde

42 Bkz. Maximilian Lakitsch, "Islam in the Syrian War: Spotting the Various Dimensions of Religion in Conflict", Religions 9, sy 8 (2018): 1-17.

43 Halil Aydınalp, "Sosyal Çatışma ve Din”, Uludă̆ Üniversitesi İlahiyat Fakültesi Dergisi 19, sy 2 (2010): 205.

44 Mehmet Ali Büyükkara, "Mezhepsel Uzlaşma ve Barış: Modern ve Postmodern Yaklaşımlar", Divan Disiplinlerarası Çalışmalar Dergisi 18, sy 35 (2013): 116.

45 Bkz. Talip Özdeş, “Çatışma veya Uzlaşma 21. Yüzyıla Girerken Çoğulculuğa Kur'an Açısından Bir Bakış", Cumhuriyet Üniversitesi Illahiyat Fakültesi Dergisi, sy 4 (2000): 184.

46 Münazara geleneğinin çatışma nedeni sayılmasıyla ilgili detaylı bilgi için bkz. Yaka, Sosyoloji Yazıları Çatışma Kültüründen Uzlaşma Kültürüne, 355-57.

47 Bkz. Ahmet İnan, “Kur'anda Uzlaşmanın Anahtar Kavramları”, içinde Kur'an 'nın Farklı İnanç Mensuplarına Yaklaşımı Sempozyumu (Konya: Konya İlahiyat Derneği Yayınları, 2007), 154-56; 161.

48 Bkz. Hüseyin Yılmaz, Din Eğitimi ve Sosyal Barış (İstanbul: İnsan Yayınları, 2003), 20-32.

49 Temel Yeşilyurt, “'Ben'in ‘Öteki'leşmesi ya da Söylemin Ayrıllı̆ı Çatışma Teolojisinden Uzlaşma Teolojisine”, Islamiyat 7, sy 3 (2004): 149-51.

50 Bu tanımı destekler nitelikte bilgiler için bkz. Muhammet Şevki Aydın ve Cemil Osmanoğlu, Kültürlerarası Din Eğitimi (Ankara: Nobel Akademik Yayıncılık, 2015), 143-49; Muhammet Şevki Aydın, Açık Toplumda Din Eğitimi Yeni Paradigma İhtiyacı (Ankara: Nobel Akademik Yayınc1lık, 2018), 108-12. 
tanımlanabilir. Dinî uzlaşma anlayışının baskın olmadığı ortam ve zamanlarda dinî meselelerde ortaya çıkan çatışmaların yaygınlaştığı kültür de dinî çatışma kültürü olarak yorumlanabilir. ${ }^{51}$

\section{İlahiyat Lisans Programı ve Uzlaşma}

Türkiye'deki pek çok ilahiyat fakültesine benzer şekilde Recep Tayyip Erdoğan Üniversitesi (RTEÜ) İlahiyat Fakültesinde de ${ }^{52}$ programın genel çıktıları arasında; dinî konularda bireysel farklılıkları dikkate alarak hizmet sunma, elde edilen bilgileri farklı bir ortama aktarma ve kullanma, dinî konularda günceli takip ederek çözümler üretme, toplumsal sorunlara duyarlı olma, dinî konularda doğru ve yanlış bilgiyi ayırt etme ve farklı dinî akımları teolojik ve kuramsal yapılarıyla tanıyıp kavrama gibi çeşitli öğrenme çıktıları yer almaktadır. Program çıktıları arasında yer verilen dinî konularda doğru bilgi elde edip doğru ile yanlışı birbirinden ayırt etme ve ardından bunu muhataplarına uygun şekilde aktarma, teoride dinî uzlaşma anlayış ve kültürünün öğrenciler tarafından benimsenmesine katkı sağlayacak başlıklar arasındadır.

RTEÜ İlahiyat Fakültesi programında Temel İslam Bilimleri (TİB) alanına ait derslerin \%49'luk oranla programdaki en yoğun alan olduğu görülmektedir. TİB alanına ait derslerin öğrenme çıktıları incelendiğinde genel olarak alan bilgisinin edinilmesine ağırlık verildiği dikkat çekmektedir. Ancak dinî uzlaşma kültürünün yaygınlaşması için bireyin inandığı din hakkında doğru bilgiye sahip olmasının yanı sıra uzlaşma için gereken şartlarda da belirtildiği üzere farklılıklara açık olma, empati, sağlıklı iletişim kurma ve yaratıcı çözümler üretme gibi bileşenleri de kazanması beklenir. Her ne kadar TİB alanına ait derslerin öğrenme çıktıları arasında dinî uzlaşma anlayış ve kültürü için önemli olan kendini tanıma, ötekileştirmeme, müzakereye açık olma vb. unsurlara fazla yer verilmediği dikkat çekse de İslam hukuku, İslam mezhepleri tarihi ve tefsir gibi bazı derslerde dinî uzlaşma kültürüne belli düzeyde katkı sağlayacak öğrenme çıktılarının olduğu söylenebilir.

Buna karşın programda \%16'lık oranla ikinci ağırlıkta olan Felsefe ve Din Bilimleri (FDB) alanına ait din eğitimi, din psikolojisi, din sosyolojisi, din felsefesi, mantık, dinler tarihi gibi derslerin öğrenme çıktıları incelendiğinde bilgi

51 Dinî uzlaşma ve çatışma kültürü kavramlarının tanımları Yaka'nın uzlaşma ve çatışma kültürüne dair yazısından esinlenerek yazılmıştır. Krş. Yaka, Sosyoloji Yazıları Çatışma Kültüründen Uzlaşma Kültürüne, 261-65; Dinî barış ve savaş dönemleri için bkz. Özdeş, "Çatışma veya Uzlaşma 21. Yüzyıla Girerken Çoğulculuğa Kur'an Açısından Bir Bakış”, 180-82.

52 “Recep Tayyip Erdoğan Üniversitesi İlahiyat Fakültesi Lisans Programı”, Recep Tayyip Erdoğan Üniversitesi İlahiyat Fakültesi, Erişim 25 Kasım 2018, http://bologna.erdogan.edu.tr/ organizasyonInfo.php?kultur=tr-TR\&mod=1\&program=237\&yil=2019. 
düzeyinin ötesinde uzlaşma için gerekli olduğu varsayılan toplumsal bütünlüğü sağlama, yaratıcılık, farklılıklara ve eleştiriye açık olma gibi pek çok unsurla karşılaşılmaktadır. İlahiyat programında $\% 9$ gibi düşük bir orana sahip olan İslam Tarihi ve Sanatları (ITS) alanına ait derslerin öğrenme çıtılarının ise genelde bilgi odaklı olduğu ve bu haliyle dinî uzlaşma kültürüne etkisinin TİB alanıyla benzer şekilde olacağı söylenebilir. Bu alanların yanı sıra programda üniversite ortak zorunlu derslerinin $\% 4$, pedagojik formasyon derslerinin $\% 11$, seçmeli derslerin de \%11'lik bir ağırlığa sahip olduğu görülmektedir. Bunlardan içerikleri itibariyle pedagojik formasyon dersleri ve ortak derslerin büyük oranda FDB alanındaki derslere yakın durduğunu belirtmek gerekir.

\section{Yöntem}

Bu araştırmada ilahiyat eğitiminin dinî uzlaşma kültürüne etkisi mevcut hâliyle ve derinlemesine incelenmek istendiği için nitel yöntem ${ }^{53}$ kullanılmıştır. Araştırmada; öğrencilerin uzlaşma, çatışma, öteki, empati ve iletişim kavramlarına yönelik düşüncelerinin tam olarak görülebilmesi için fenomenolojik araştırma deseninden, ${ }^{54}$ mevcut durumun olduğu gibi ortaya konulması ve konunun derinlemesine incelenmesi için durum çalışması deseninden ${ }^{55}$ ve öğrencilerin kendi arkadaşlarılyla ve hocalarıyla, sınıf ortamındaki ve sosyal hayattaki ilişkileri ele alındığı için kültür analizi deseninden ${ }^{56}$ faydalanılmıştır.

Araştırmanın ulaşılabilir evrenini ${ }^{57}$ 2018-2019 öğretim yılında RTEÜ İlahiyat Fakültesinde eğitim gören 4. sınıf öğrencileri oluşturmaktadır. Bu evrenden çalışma

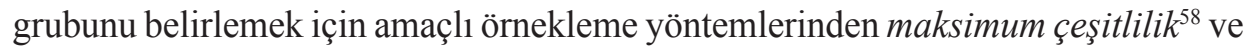
kartopu örneklemesi $i^{59}$ yöntemlerine başvurulmuştur. Araştırma evrenindeki çeşitliliği yansıtmak için tercih edilen maksimum çeşitlilik örneklemesiyle öğrencilerin

53 Michael Quinn Patton, Nitel Araştırma ve Değerlendirme Yöntemleri, çev. Mesut Bütün ve Selçuk Beşir Demir (Ankara: Pegem Akademi, 2018), 14.

54 Ali Yıldırım ve Hasan Şimşek, Sosyal Bilimlerde Nitel Araştırma Yöntemleri (Ankara: Seçkin Yayınc1lı, 2016), 69-72.

55 Detaylı bilgi için bkz. Yıldırım - Şimşek, Sosyal Bilimlerde Nitel Araştırma Yöntemleri, 289302; Ayrıca bkz. Creswell, Nitel Araştırma Yöntemleri Beş Yaklaşıma Göre Nitel Araştırma ve Araştırma Deseni, 96-102.

56 Bkz. Creswell, Nitel Araştırma Yöntemleri Beş Yaklaşıma Göre Nitel Araştırma ve Araştırma Deseni, 90-96; Yıldırım ve Şimşek, Sosyal Bilimlerde Nitel Araştırma Yöntemleri, 67-69.

57 Evren türleriyle ilgili olarak bkz. Şener Büyüköztürk vd., Bilimsel Araştırma Yöntemleri (Ankara: Pegem Akademi, 2017), 82-83.

58 Yıldırım ve Şimşek, Sosyal Bilimlerde Nitel Araştırma Yöntemleri, 119-20.

59 Patton, Nitel Araştırma ve Değerlendirme Yöntemleri, 237-38; Y1ldırım ve Şimşek, Sosyal Bilimlerde Nitel Araştırma Yöntemleri, 112. 
cinsiyetleri, öğrenim gördükleri program türleri ve mezun oldukları liseler baz alınırken; araştırma konusuyla ilgili kritik durumları ortaya çıkarma noktasında bilgi sahibi olan bireylere ulaşmayı sağlayan kartopu örnekleme yöntemiyle de çalışma grubu genişletilmiştir. Bu doğrultuda çeşitliliğin sağlanması dikkate alınarak, önce araştırma konusunda yorum yapabilecek öğrencilere ulaşılmış, ardından bu öğrencilerden alınan yeni isimlerle görüşmeler yapılarak çalışma grubu büyütülmüştür.

Tablo 1.

Çalışma Grubuna Ait Temel Veriler

\begin{tabular}{|l|c|c|c|c|}
\hline No & Rumuz & Cinsiyet & Program & $\begin{array}{c}\text { Mezun Olunan Lise } \\
\text { Türü }\end{array}$ \\
\hline 1 & Ali & Erkek & İkinci Öğretim & İHL \\
\hline 2 & Cihan & Erkek & İkinci Öğretim & İHL \\
\hline 3 & Derya & Kadın & İkinci Öğretim & İHL \\
\hline 4 & Kadir & Erkek & İkinci Öğretim & İHL \\
\hline 5 & Melike & Kadın & İkinci Öğretim & Diğer \\
\hline 6 & Mehmet & Erkek & İkinci Öğretim & İHL \\
\hline 7 & Ayşe & Kadın & İkinci Öğretim & İHL \\
\hline 8 & Ece & Kadın & İkinci Öğretim & İHL \\
\hline 9 & Feride & Kadın & İkinci Öğretim & İHL \\
\hline 10 & Reyhan & Kadın & Birinci Öğretim & İHL \\
\hline 11 & Akif & Erkek & Birinci Öğretim & Diğer \\
\hline 12 & Hasan & Erkek & Birinci Öğretim & İHL \\
\hline 13 & Mert & Erkek & Birinci Öğretim & İHL \\
\hline 14 & Cansu & Kadın & Birinci Öğretim & İHL \\
\hline 15 & Pelin & Kadın & İkinci Öğretim & Diğer \\
\hline 16 & Sümeyye & Kadın & Birinci Öğretim & İHL \\
\hline 17 & Ömer & Erkek & Birinci Öğretim & Diğer \\
\hline 18 & Beyza & Kadın & Birinci Öğretim & İHL \\
\hline 19 & Gülçin & Kadın & Birinci Öğretim & Diğer \\
\hline 20 & Furkan & Erkek & Birinci Öğretim & İHL \\
\hline 21 & Selim & Erkek & Birinci Öğretim & İHL \\
\hline 22 & Yavuz & Erkek & İkinci Öğretim & İHL \\
\hline 23 & Fatih & Erkek & İkinci Öğretim & İHL \\
\hline 24 & Burak & Erkek & İkinci Öğretim & İHL \\
\hline 25 & Ayla & Kadın & Birinci Öğretim & İHL \\
\hline 26 & Cemre & Kadın & Birinci Öğretim & İHL \\
\hline 27 & Burcu & Kadın & Birinci Öğretim & Diğer \\
\hline
\end{tabular}

Araştırmada veri toplama tekniği olarak literatür taramasi ${ }^{60}$ ve görüşmeden ${ }^{61}$ faydalanılmıştır. Yapılan görüşmelerde araştırmacılar tarafindan hazırlanan yirmi üç soruluk yarı yapılandırılmış görüşme formu ${ }^{62}$ kullanılmıştır. Toplam yirmi yedi

60 Büyüköztürk vd., Bilimsel Araştırma Yöntemleri, 47-48.

61 Durmuş Ekiz, Bilimsel Araştırma Yöntemleri (Ankara: Anı Yayıncılık, 2017), 62.

62 Bkz. Yıldırım ve Şimşek, Sosyal Bilimlerde Nitel Araştırma Yöntemleri, 132; Ekiz, Bilimsel Araştırma Yöntemleri; Patton, Nitel Araştırma ve Değerlendirme Yöntemleri, 343-44. 
öğrenciyle yapılan görüşmeler 27 Aralık 2018-21 Mart 2019 tarihleri arasında gerçekleştirilirken, öğrencilerin tamamına görüşme başlamadan önce araştırma hakkında bilgi veren ve araştırmaya gönüllü olarak katıldıklarını gösteren bir onam formu imzalatılmıştır.

Literatür taramasıyla toplanan veriler, doküman analiziyle çözümlenmiş ve araştırmanın temaları bu süreçte belirlenmiştir. Bu bağlamda ilk tema olarak uzlaşma ele alınmış, ardından uzlaşmanın zıddı olan çatışmaya yer verilmiş, sonra da her iki kavramın ilişkili olduğu ve uzlaşma için önemli gördüğümüz öteki ve empati-iletişim tema olarak tespit edilmiştir. Ancak konunun daha iyi anlaşılması için temalar; öteki, çatışma, empati-iletişim ve uzlaşma şeklinde sıralanmıştır. Öğrencilerin uzlaşmaya dair düşüncelerine ulaşmak için, öncelikle öğrencilerin uzlaşmaya etki eden faktörlerle ilgili görüşlerini vermenin daha doğru olacağı düşüncesinden hareket edilmiş ve bu nedenle bahsedilen sıralama takip edilmiştir. Görüşme tekniğiyle elde edilen verilerin analiz sürecinde ise öncelikle görüşme yapılan öğrencilerin adları, kimsenin deşifre edemeyeceği rumuz isimleriyle değiştirilmiştir. Bu işlemin akabinde veriler, Tablo 2'de de görüleceği üzere önceden belirlenen dört ana temaya göre tasnif edilmiş, ardından anlamlı bir bütün meydana getirecek çeşitli kodlara ayrılmış ve bu kodlardan hareketle kategoriler oluşturulmuştur. ${ }^{63}$ Ayrıca öğrenci görüşlerinin analizi esnasında betimsel analiz ${ }^{64}$ ve içerik analizi ${ }^{65}$ tekniklerinden hareket edilmiştir. ${ }^{66}$

63 Kod, kategori ve tema için bkz. Yıldırım ve Şimşek, Sosyal Bilimlerde Nitel Araştırma Yöntemleri, 243-53; Patton, Nitel Araştırma ve Değerlendirme Yöntemleri, 263-67.

64 Bkz. Yıldırım ve Şimşek, Sosyal Bilimlerde Nitel Araştırma Yöntemleri, 239-41; Ekiz, Bilimsel Araştırma Yöntemleri, 76.

65 Bkz. Nuri Bilgin, Sosyal Bilimlerde İçerik Analizi Teknikler ve Örnek Çalışmalar (Ankara: Siyasal Kitabevi, 2006), 11-16; Yıldırım ve Şimşek, Sosyal Bilimlerde Nitel Araştırma Yöntemleri, 242-54; Ekiz, Bilimsel Araştırma Yöntemleri, 77; Patton, Nitel Araştırma ve Değerlendirme Yöntemleri, 252-53.

$66 \mathrm{Bu}$ makalede, çalışmanın sınırlarına riayet edilmesi için öğrenci mülakatlarından elde edilen verilerin asgari düzeyde kullanılması yolu tercih edilmiştir. 
Tablo 2.

Tema ve Kategori Listesi

\begin{tabular}{|c|c|}
\hline Tema & Kategori \\
\hline \multirow{4}{*}{ Öteki } & Ötekinin Tanımlanması \\
\hline & Hakikat Algıları \\
\hline & Kur'an-1 Kerim ve Öteki Algis1 \\
\hline & İlahiyat Eğitiminin Ötekileştirmeye Etkisi \\
\hline \multirow{4}{*}{ Çatışma } & Çatışmanın Tanımlanması \\
\hline & Çatışmanın Sonuçları \\
\hline & İlahiyat Eğitiminin Çatışma Çıkarmaya Etkisi \\
\hline & İlahiyat Eğitiminin Çatışma Çözümüne Etkisi \\
\hline \multirow{4}{*}{ Empati ve İletişim } & İlahiyat Eğitiminin Empati, Sempati ve Antipatiye Etkisi \\
\hline & İlahiyat Eğitiminin Empati Becerisine Etkisi \\
\hline & İlahiyat Eğitiminin İletişim Kurma Becerisine Etkisi \\
\hline & İlahiyat Eğitiminin Muhalif Düşünceleri İfade Edebilmeye Etkisi \\
\hline \multirow{5}{*}{ Uzlaşma } & Uzlaşmanın Tanımlanması \\
\hline & İslam ve Uzlaşma \\
\hline & İlahiyat Eğitiminin Yoruma İmkân Sağlama Durumu \\
\hline & İlahiyat Eğitimi ve Uzlaşma Arasındaki İlişki \\
\hline & İlahiyat Eğitiminin Uzlaşma Anlayışına Etkisi \\
\hline
\end{tabular}

\section{Bulgular ve Tartışma}

\section{Öteki}

İlahiyat eğitimi alan öğrencinin dinî mevzularda kendinden farklı düşünen muhatabına karşı çatışmacı ya da uzlaşmacı bir yaklaşım benimsemesinde sahip olduğu öteki algısının belirleyici olacağı açıktır. Çünkü kişinin ötekine bakışı, söz konusu yaklaşımlardan hangisinin kendi karakterinde baskın hâle geleceği noktasında önemli bir role sahiptir. Bu doğrultuda öğrencilere öteki, ötekileştirme ve dinî ötekine dair sorular sorulduğunda, cevaplarının dört kategoride toplandığı görülmüştür.

İlk kategoride öğrencilerin muhataplarının duygu, düşünce, inanç ve davranışlarına yönelik tutumlarını görme maksadıyla onlara öteki ve ötekileştirmeyle ilgili sorular yöneltilmiş; gelen cevaplar, dışlayıcılık ve kapsayıcılık olmak üzere iki alt kategoriye ayrılmıştır. Ötekini dışlayıcı yaklaşımla tanımlayan öğrencilerin çoğu, gündelik hayatlarında da dışlayıcı tavrı sürdürdüğünü, kalan kısmı ise tanımlarının aksine pratik hayatlarında daha kapsayıcı bir yaklaşıma yöneldiğini ifade etmiştir. Ötekine karşı kapsayıcılı̆̆ 1 esas aldığını belirten öğrenciler ise öteki kavramını daha çok düşünsel düzlemde değerlendirmişlerdir. Burada asıl dikkat çeken husus, öğrencilerin bir kısmının söyledikleriyle yaptıklarının bazı noktalarda çelişmesidir. Sözgelimi kendisinin ötekine karşı dışlayıcı tavra sahip 
olmadığını beyan eden bir öğrenci, aynı zamanda kendi doğrularını karşı tarafa kabullendirme içgüdüsüne de sahiptir. Bunlardan biri olan Mehmet, fikirlerini şu şekilde dile getirmiştir: "Toplumda bir şeyi, bir insan söylediği zaman, eğer toplum onu kabul etmiyorsa hemen ötekileştirme olur. Ancak bu durum Müslümanlara yakışmaz. ... Sıkıntılı gördüğüm bir kişi hakkında şunu derim: Ben bu çocukla oturdum, bu çocukta bazı problemler var. Yani biraz imanı zayıf, dinî fikir olarak imanı zayıf bir arkadaş, deistliğe kayıyor, bunun elinden tutalım, bizim hocamıza götürelim, bir şey yapalım." Kuşkusuz inanılan dinin ya da dinî görüşün hakikat olarak telakki edilmesi, bu tezadı açıklayabilir. Ayrıca öğrencilerin kendilerine dışlayıcılığı yakıştırmadıkları için kapsayıcı söylemde bulunmaları, inandıkları dinî görüşü hakikat olarak kabul etmeleri ve hakikat olduğunu düşündükleri bilgilere dair yorum farkl1l1klarına müsamaha gösterilemeyeceği inancına sahip olmalar1 ${ }^{67}$ da bu durum için açılayıı bir nedendir.

Hakikat algısı, dinî ötekine dışlayıcı ya da kapsayıc1 ${ }^{68}$ şekilde yaklaşmanın önemli bir boyutunu oluşturduğu için ikinci kategoride öğrencilerin hakikate dair fikirlerine müracaat edilmiştir. Öğrencilere bu bağlamda sorular sorulduğunda çoğu, hakikatin tek olduğunu ifade etmekle birlikte, hakikate götüren çeşitli yollara ve farklı fikirlere doğruluk payesi atfetmiştir. Fakat bu doğruluk değerini tek olduğuna inandığ 1 hakikatle yani İslam diniyle ve özellikle itikadi sahayla sınırlandırırken, sadece bu haddin dışında kalan farklı yollara ve fikirlere kapı aralamıştır. Öğrencilerin büyük bir kısmı tarafından farklı yol şeklinde ele alınan İslam mezheplerinin bir taraftan rahmet kaynağı diğer taraftan ise toplumsal hayatta cereyan eden çatışmaların müsebbibi olarak görülmesi dikkat çekicidir. Zira öğrencilerin de mezheplerle ilgili altını çizdikleri ikileme düştükleri görülmüştür. Öğrencilerden biri (Melike), bu konuyu şu şekilde açıklamıştır: "Bence mezhepler rahmettir. Ancak ne yazık ki pratik hayatta mezheplere rahmet olarak bakılmıyor. $\mathrm{Bu}$ bağnazlık, taassup, katı görüşlerimiz yahut uzlaşmayı sağlayamamamızla alakalı bir durumdur. Çünkü sen eğer uzlaşmayı sağlarsan mezhepleri bölücülük olarak değil de bir rahmet olarak görürsün. ... Buna karşın mezhepler arası geçiş sürekli olmamalıdır bunun da görüşündeyim. ... Dışarıda ne yazık ki mezhepler arasında sıkı bir set çekilmiş, kimse kimseye selam bile vermez olmuş..." Bu ikilem, öğrencilerin hem öteki tanımlarında hem de hakikatle ilgili algılarında benzer şekilde zuhur etmektedir.

67 Çok kültürlü toplum üzerinden konuyu ele alan Gündoğdu'nun, çalışmasında yer verdiği ötekine karşı tutumla ilgili maddeler, burada ileri sürdügüümüz kanıyı destekler niteliktedir. Bkz. Hakan Gündoğdu, "Çok Kültürlü Bir Toplumda Ötekiyle Yaşamak ve Hoşgörü”, EKEV Akademi Dergisi, 37 (2008): 80.

Bkz. Aydın, "Paradigmanın Yeni Adı: Dinsel Çoğulculuk”, 26-32. 
Çoğunluğun bu fikrine karşın ikinci grubu oluşturan öğrenciler ise hakikatin tek olduğu fikrine katılmayarak, bu durumu inançlar ve dinler üzerinden değerlendirmişlerdir. Örneğin Akif, bu konuda şunları ifade etmiştir: "Hakikat tek olsa zaten herkes ona inanırdı, bu inanç boyutu zaten. Mesela Allah gelip şu dağın başında otursaydı, ona herkes inanırdı, değil mi! Allah zaten orada oturmuş haşa. Herkes ona inanır, çünkü zaten nesnel olarak görüyorsun; ama hakikat, öznel anlamda olduğu için dinler, inançlar, özgürlükler, fikirler noktasında hakikatin tek olduğunu diyemiyoruz. Kendime göre hakikat tek olabilir, ama bana göre tektir. İşte ben, bana göre bu tekliği alıp, bütün dünyaya, çevreme uygulamaya kalkarsam çatışma olur ve bu büyük bir sorun doğurur."

Sosyal psikoloji açısından insanların bir mezhebe mensubiyeti sosyal gruba aidiyet olarak değerlendirilebilir ve bu açıdan bir mezhebe bağlı olmak toplumsal anlamda bir problem teşkil etmez. Fakat Yapıcı ve Albayrak, ${ }^{69}$ bahsi geçen durumun dinî gruplara göre farklılık gösterdiğini belirterek; bunun hakikat algısıyla alakalı olduğuna işaret etmiş ve bu algının dışlayıcılığa sebebiyet verdiğinin altını çizmişlerdir. Mevzuyu benzer doğrultuda ele alan Bulut, ${ }^{70}$ bu durumun neticesinde "hakikat tekelciliğinin" zuhur edebileceğine dikkat çekmiştir. Ayrıca Bulut'un araştırmasına katılan öğrencilerin çoğunun da dinî grupları; hakikati kendilerine ait görme, ayrıştırıcılık, ötekileştirme, dışlama, birlik ve beraberliği bozma gibi noktalardan eleştirdiği görülmüştür. Nitekim dinî grupların 73 firka hadisini ${ }^{71}$ yorumlarken hakikati kendilerinin temsil ettiğini belirtmesi de bu durumun kanıtıdır. Yanlış eğitimle çocukların kendilerine ötekileştiğine işaret eden Başkurt, ${ }^{72}$ bunun sonucunda mezheplerin, cemaatlerin ve dinî grupların hakikati söyleyen tek kanal olarak algılandığını ve onların eleştirilemez, görüşleri üzerine konuşulamaz, aşılamaz olarak görüldüğünü vurgulamıştır. Bu durum, bireylerin toplum içerisinde birbirlerini ötekileştirmeleri sonucunu doğurur. Bu araştırmaya katılan öğrencilerin

69 Yapıcı ve Albayrak'ın çalışmasının temel noktası farklı dinleri ele alsa da aynı din içerisinde de benzer tezahürlerin olabileceği düşünülmektedir. Bkz. Asım Yapıcı ve Kadir Albayrak, “'Öteki’ni Algılama Bağlamında Dinî Gruplar Arası İlişkiler”, Dini Araştırmalar 5, sy 14 (2002): 36-38; Dinlerdeki hakikate bakış ve öteki algısı için ayrıca bkz. Şevket Yavuz, “'Öteki' ile 'Beriki' Arasındaki Salınımda Dinlerde Birlikte ve Beraber Yaşamanın Teolojik ve Pratik İmkanı”, Milel ve Nihal: Inanç, Kültür ve Mitoloji Araştırmaları Dergisi 6, sy 2 (2009): 32-35.

70 Ramazan Bulut, "İslami İlimler Fakültesi Öğrencilerinin Dini Gruplar Hakkındaki Görüşleri Üzerine Bir Araştırma”, Dinbilimleri Akademik Araştırma Dergisi 20, sy 1 (2020): 376-80.

71 Muhammet Emin Eren, “İslam Toplumunda Ayrıştırıcı/Ötekileştirici Söylemin Oluşumunda İftirak (73 Frrka) Hadisinin Rolü”, içinde Kur'an ve Toplumsal Bütünleşme (Mezhepler ve Dini Gruplar Arası İlişkiler), ed. Hayati Hökelekli ve Vejdi Bilgin (Bursa: Bursa Büyükşehir Belediyesi Yayınları, 2015), 19-34.

72 İrfan Başkurt, “Eğitimde Çocuk ve ‘Öteki’nin Kimliği Problemi”, İstanbul Üniversitesi İlahiyat Fakültesi Dergisi, sy 5 (2002): 113-41. 
de kendilerinin dışlayıcı bir tutuma sahip olmadığını söylemelerine rağmen, bilinçaltlarında kendi hakikatlerini karşı tarafa kabullendirme isteğinin yatması, bahsedilen hakikat algısıyla ilgili olsa gerektir.

İslam teolojisinin merkeze alındığı yüksek din öğretimi kurumlarında, öğrencilerin dinî öteki ve hakikatle ilgili görüşlerinin referans noktasını Kur'an-1 Kerim oluşturduğu için üçüncü kategoride Kur'an-1 Kerim'deki öteki algısı ele alınmıştır. Buradan hareketle öğrencilere göre Kur'an-1 Kerim'in ötekine bakış1, hoşgörüyle ve ötekileştirmeden yaklaşma şeklinde iyimser bir perspektife sahiptir. Buna karşın öğrencilerin önceki kategorilerde yer alan öteki ve hakikatle ilgili fikirleri, kendilerinin Kur'an-1 Kerim'in aksine daha dışlayıcı bir karaktere sahip olduklarını göstermekte ve bu durum bir çelişki gibi durmaktadır. Burada gözden kaçırılmaması gereken temel husus, öğrencilerin Kur'an-1 Kerim'in farklı dinî görüş ya da dinlere karşı hoşgörülü olmayı ve ötekileştirmeden yaklaşmayı tavsiye ettiğine işaret etmelerine rağmen, tek olan hakikate inanmadıkları sürece o kimselere kurtuluş imkân ${ }^{73}$ tanımadığının altını çizmeleridir. Öğrencilerin zihinsel arka planlarını anlaş1lır kılacak şekilde Furat, ${ }^{74}$ İslam toplumunun kimlik oluşumunda Kur'an-1 Kerim ve sünnette yer alan inananlar ve inanmayanlar ayrımının önemine dikkat çekmiş ve bu ayrımın inananların inanmayanlara karşı üstün geleceği fikrini filizlendirdiğine işaret etmiştir. Bunun neticesinde İslam toplumunda, inananların yani Müslümanların kurutuluşa ereceği inancının yeşerdiği söylenebilir. Dikkat çeken ikinci husus ise öğrencilerin aldıkları dersler sayesinde kendilerinin ötekine daha olumlu baktıklarını belirtmekle birlikte, toplumsal hayatta ötekine karşı olumsuz bir tavrın hüküm sürdügünü ifade etmeleridir. Nitekim öğrenciler, kendi dinlerine saygı duyulması için öteki inanç mensuplarına ve dinî görüşlere karşı ihtiyatlı yaklaşma ${ }^{75}$ saygılı olma, merhametli olma, kardeşçe yaklaşma ${ }^{76}$ gibi hususlara dikkat edilmesi gerektiğini dile getirmişlerdir.

İslam dini içindeki öteki olgusunu dinde zorlama yoktur ayetinden hareketle değerlendiren Bilgin ${ }^{77}$ ise İslam'a girdikten sonra insanlara zorlamanın yapılabileceğine dair yorumların uç fikirler olduğuna dikkat çekerken, tüm Müslümanların bu tavra

73 Bakara 2/112; Âl-i İmrân 3/85.

74 Ayşe Zişan Furat, İslam Toplumunda Kimlik Oluşumu ve Din Eğitimi (Konya: Yediveren Kitap, 2013), 60-67.

75 Bkz. İsmail Çalışkan, “Dini Bir Tutum Olarak Ötekine Yaklaşımın Kur'anî Temelleri”, Cumhuriyet Üniversitesi İlahiyat Fakültesi Dergisi 11, sy 1 (2007): 7-28.

76 Bkz. Şevket Yavuz, “İslâm’ın Ötekileştirmeye Meydan Okuması veya 'Ontolojik Öteki'den 'Vasıfsal Öteki'ne İntikalin Macerası”, Marife, sy 3 (2006): 135-56.

77 Bkz. Beyza Bilgin, “İslam'da Ötekine Bakış”, Ankara Üniversitesi İlahiyat Fakültesi Dergisi 42, sy 1 (2001): 11-40. 
sahip olmadığını da vurgulamıştır. Kur'an-1 Kerim'de ilke olarak ötekileştirmenin olmadığını belirten Sülün ${ }^{78}$ de Bilgin'le benzer şekilde insanların farklı dinler, mezhepler, cemaatler gibi çeşitli nedenlerle birbirlerini ötekileştirdiğine işaret ederken gerek dinlerin gerekse din içi gruplar arasında yaşanan ötekileştirme ve çatışma ortamlarının da dinden değil, dinin inanırlarından kaynaklandığını ifade etmiştir. Öğrenciler de söylemde kendilerini, Bilgin ve Sülün'ün ifadelerine uygun bir şekilde konumlandırmaktadırlar. Örneğin Reyhan, bu hususta şunları dile getirmiştir: "Kur'an-1 Kerim, dinimiz zorlayıc1, otoriter, baskıcı bir din değildir. Sanki İslam'1 Allah değil de biz kurmuşuz gibi, altına bütün maddeleri biz yazmışız gibi, biz böyle katı kuralları koyuyoruz, otoriter davranıyoruz."

Öteki, hakikat ve Kur'an-1 Kerim'in ötekine bakışı hususlarında eğitimin etkili olacağ 1 düşüncesinden hareketle son kategoride ilahiyat eğitiminin öğrencilere bu konularda katkı sağlama durumuna yer verilmiştir. Bu noktada öğrencilerin hadis, kelam, tefsir gibi TİB alanına ait derslerin öteki algısı üzerinde kimi zaman olumlu kimi zaman olumsuz yönde tesirli olduğunu ifade ederken; FDB alanındaki din eğitimi, din sosyolojisi, din psikolojisi, dinler tarihi, felsefe ve bunun yanı sıra formasyon derslerinin ise daha çok olumlu anlamda katkı sağladığını belirtmeleri dikkat çekmiştir. Mesela Selim, mevzuyu TİB dersleri üzerinden şu şekilde ele almıştır: "Dersler ötekileştirmeye neden olabiliyor. Örneğin İslami ilimlerde; hadis ve İslam hukuku bu konuda daha ağırlıklı. Bu daha çok hocanın tutumuyla alakalı bir durum. Eğer hocanın tutumu farklı görüşlere biraz daha uyuşmacı olursa, o zaman sıkıntı olmuyor..." Ece ise bu hususta genel bir değerlendirme yapmıştır: "Burada bize rahatça görüşünü sunma imkânı tanınıyor. Felsefe, din sosyolojisi, din psikolojisi, tefsir ve kelam derslerimiz de daha çok görüşümüzü sunup, karşımızdakinin görüşünü anlayabilmeyi sağlıyor...” Öğrencilerin değerlendirmeleri ders içerikleri ve kazanımlarıyla da örtüşür mahiyettedir. Söz gelimi öğrenciler tarafindan olumlu etki ettiği belirtilen din felsefesinde dinî inançlar konusunda rasyonel, objektif, tutarlı davranma, farklı dinî inançları eleştirel bakış açısıyla yeniden düşünme, eleştiriye açık olma gibi kazanımlara yer verildiği görülürken; buna karşın tefsir dersinde bilgi odaklı kazanımlar ve inanç merkezli ders içeriğiyle karşılaşılır. Bu misal, öğrencilerin derslerin katkılarına yönelik görüş farklılıklarını açıklayıcı niteliktedir.

Öğrencilerin daha kapsayııı bir bakış açısına sahip olmasında FDB derslerinin belirleyici olduğunu düşünen Taşkıran, ${ }^{79}$ bu derslerin öğrencilerin dini anlama ve

78 Bkz. Murat Sülün, “Sevgi ve Nefret Bağlamında Kuran’a Göre Öteki: -Kimi Sevip Kimi Sevmeyeceğiz?-”, içinde İslam 'da Sevgi Temelinde Beşeri Münasebetler-İlmi Toplantr, 2010, 317-35.

79 Bkz. Ayşe Taşkıran, "İlahiyat Fakültesi Müfredatında Felsefe ve Din Bilimleri Bölümü Derslerinin Yeri ve Fonksiyonlarına Dair Bir Araştırma (İlahiyat Fakültesi Öğrencileri Örneği)", Kahramanmaraş Sütçü İmam Üniversitesi İlahiyat Fakültesi Dergisi 11, sy 22 (2013): 238-52. 
anlamlandırma çabalarının bilinçli hâle gelmesinde etkili olduğu sonucuna varmış ve böylece insanların birbirlerine karşı daha anlayışlı, farklı inanç gruplarına karşı daha hoşgörülü olacağını vurgulamıştır. Nitekim Taşkıran' $1 n^{80}$ çalışmasındaki öğrencilerin çoğu da FDB dersleriyle birlikte dinî konularda olumlu bir perspektif geliştirdiklerine işaret etmiştir. Tıpkı Taşkıran gibi Toktaş ve Acuner ${ }^{81}$ de felsefe derslerinin dini daha iyi anlama ve tutarlı bakış açısı geliştirme noktasında öğrencilere katkı sağladığının altını çizmişlerdir. Benzer şekilde Altaş ve Büyük ${ }^{82}$ de din felsefesi dersinin öğrencilerin dinî inançlarını derinlemesine anlamasına ve kavramasına imkân verdiğini belirtmişlerdir.

\section{Çatışma}

Her şey zıddıyla kaimdir ilkesinden hareketle dinî uzlaşma anlayışı ve kültürünün daha iyi anlaşılabilmesi için ikinci temada çatışma kavramı ele alınmıştır. Bu bağlamda öğrencilerin ilahiyat eğitimiyle çatışma arasındaki ilişkiye dair görüşlerine müracaat edilmiş ve cevapları dört kategoride toplanmıştır.

İlk kategoride öğrencilerin çatışma konusundaki fikirlerinin geniş bir yelpazeye sahip olduğu görülmüştür. Farzı misal çatışmayı farklı fikirlerin uyuşamaması olarak gören Hasan düşüncelerini "Bir konu üzerinde kişilerin veya grupların farklı şeyler düşünmesi, farklı söylemler ortaya koyması” şeklinde açıklarken; çatışmayı uzlaşmanın zıddı olarak değerlendiren Beyza, düşüncesini "Uzlaşmanın tam tersi, karşıdaki fikrî benimseyemeyip kendi fikrini öne sürdüğünde ortaya çıan kargaşa" olarak ifade etmiş; Ali, çatışmanın farklı gruplar arasında belireceğini "İki farklı grubun, birbirini tam anlayamamasından kaynaklanan bir durum" sözleriyle dile getirirken; Ayla ise çatışmanın fiziksel şiddete varan boyutunu da ön plana çıkarmıştır: "Çatışma deyince; karşılıklı savaş, fikir çatışması, farklı düşünceler aklıma geliyor."

Öğrencilerin çatışma tanımlarındaki çeşitlilikle Koçak ve Aktaş' $1 n^{83}$ çalışmasında yer alan çatışma tanımı ve yaklaşımlarında da karşılaşılmıştır. Yanı sıra Altan ${ }^{84} \mathrm{da}$

80 Taşkıran, 253-55.

81 Bkz. Fatih Toktaş ve H. Yusuf Acuner, "İlahiyat Fakültelerinde Felsefe Dersleri Ondokuz Mayıs Üniversitesi İlahiyat Fakültesi Örneği”, Ondokuz Mayıs Üniversitesi İlahiyat Fakültesi Dergisi, sy 17 (2004): 159-75.

82 Bkz. Nurullah Altaş ve Celal Büyük, "Öğretmen Yetiştiren Bir Kurum Olarak İlahiyat Eğitiminin Genel Hedefleri Altında Din Eğitimi ve Din Felsefesi Eğitimi İlişkisi (Din Eğitimi ve Din Felsefesi İlişkisi Özel Amaçlara Nasıl Yansımalı?)”, Din ve Felsefe Araştırmaları 1, sy 2 (2018): 117-23.

83 Zahide Kübra Koçak ve Mehmet Ali Aktaş, "Çatışma ve Çatışma Yönetimi Kavramlarına Güncel Bir Bakış”, Niğde Ömer Halisdemir Üniversitesi Sosyal Bilimler Enstitüsü Dergisi 1, sy 2 (2019): 130-33.

84 Bkz. Yakup Altan, “Örgütsel Çatışma ve Etkileri”, Dumlupınar Üniversitesi Sosyal Bilimler Dergisi, sy 27 (2015). 
çatışmanın fiziksel şiddetten anlaşmazlığa kadar geniş bir anlam yelpazesine sahip olduğuna dikkat çekerken; benzer şekilde Kaya'nın ${ }^{85}$ çalışmasındaki katılımcılar da çatışmanın pek çok anlama geldiğini belirtmiş ve çatışmaların nedeni olarak sağliklı iletişim kuramama, kişisel ve akademik anlaşmazlık vb. çeşitli faktörleri sıralamışlardır. Bu veriler, öğrencilerin çatışma tanımları ve nedenlerine dair farklı bakış açıları geliştirmelerinin doğal bir durum olduğunu kanıtlar niteliktedir.

Öğrencilerin çatışmayla ilgili düşüncelerinin tutarlılığını görmek ve uzlaşmaya dair fikirlerini temellendirmek için ikinci kategoride çatışmanın sonuçları ele alınmıştır. Öğrencilerin hemen hepsinin çatışmanın doğal olduğunu ifade ederken çatışmanın sonuçlarının şiddetten bilgi üretmeye kadar geniş bir spektruma yayıldığını düşündükleri görülmüştür. Fikirlerini bu minvalde dile getiren öğrencilerden biri de Fatih'tir: “Çatışmaların sonucunda ölüm olabilir. Mezhep savaşlarını gördük, Yemen, Misır's hâlâ görüyoruz. Fakat fikirsel anlamda kişiler belli bir olgunluktaysa yeni bir bilgi de ortaya çıkabilir.” Öğrencilerin çatışma tanımlarındaki çeşitliliğin benzer şekilde burada da tezahür etmesi, öğrenci görüşlerindeki tutarlılı̆ga delil mesabesindedir. Nitekim Altan ${ }^{86}$ da hem doğumdan ölüme kadar hayatın her safhasında bulunan çatışmanın doğal olduğunun altını çizmiş hem de gelişmenin varlık göstermesi için çatışmayı bir zorunluluk addetmiştir. Görüşme yapılan öğrencilerin de bilgiye ulaşabilmek için çatışmayı gerekli görmesi, Altan'ın savıyla desteklenmiştir.

Alınan eğitimin çatışmaya yönelik bakış açısını değiştireceği düşüncesinden hareketle üçüncü kategoride, ilahiyat eğitimiyle çatışma arasındaki ilişki ele alınmıştır. Önceki kategoride öğrencilerin azımsanmayacak bir kısmının, çatışmaların olumlu da olumsuz da sonuçlanabileceğini belirtmesine rağmen; bu kategoride çoğunun, aldıkları eğitimi çatışmanın olumsuz neticelerinden yola çıkarak değerlendirmesi dikkat çekicidir. Söz gelimi Reyhan, bu konudaki görüşlerini geleneksel-modernist ayrımına dayanarak ifade etmiştir: "Geleneksel zihniyet ile biraz daha modern, biraz daha aydın, eleştirel zihniyet çatışıyor. Gelenek eleştirilemez diyenlerle, eleştirilebilir diyenler çatışıyor. Dersler de bu noktada birbirinden ayrilıyorlar." Burada üzerinde durulması gereken nokta, öğrencilerin çoğunun bu husustaki fikirlerini hocalar üzerinden dile getirmesidir. Örneğin Derya, bu hususta hocaların anlatış tarzının önemine işaret etmiştir: "Hocaların anlatış tarzından kaynaklanıyor. Çünkü biri A derken, biri B deyince öğrenci neye inanacağını şaşırıyor. Öğrenciler de hangisine uyması gerektiği hususunda arada kalıyor ve bu nedenle öğrenciler arasında çatışmalar çıkıyor. İslam mezhepleri tarihi, tefsir ve kelam derslerinde benzer durumlar yaşanıyor."

85 Bkz. Kaya Yıldız, "Üniversitelerde Çatışma ve Çatışma Yöntemi”, Abant İzzet Baysal Üniversitesi Eğitim Fakültesi Dergisi 3, sy 1 (2016): 107-24.

Bkz. Altan, “Örgütsel Çatışma ve Etkileri”. 
Akademisyen davranışlarının eğitim sürecini olumsuz yönde etkileyebileceğinin altını çizen $\mathrm{Boz},{ }^{87}$ ayrıca istenmeyen öğrenci davranışlarının da benzer sonuçlar doğuracağına işaret etmiştir. Görüşme yapılan öğrencilerin çoğu, hocaların çatışma konusunda belirleyici olduğunu düşünse de bazılarına göre hocalar bunu isteyerek yapmamaktadır. Ersanlı ${ }^{88}$ da öğretmenlerin eğitim sürecindeki rolüne işaret ederek öğretmenlerde saygı, anlayış, hoşgörü gibi vasıfların bulunmasını zaruri addetmiştir. Koç'un ${ }^{89}$ araştırmasındaki öğrenciler ise hocaların kendileriyle yetersiz ilişki kurduklarını, ihtiyaçlarını önemsemediklerini, kendilerine karşı aşırı tenkitçi, önyargılı ve hoşgörüsüz olduklarını ifade etmişlerdir. Hem Ersanlı'nın öğretmenlerde bulunmasını gerekli gördüğü nitelikler hem de Koç'un çalışmasında dile getirilen eksiklikler, görüşme yapılan öğrenciler tarafından da benzer şekilde değerlendirilmektedir.

Bazı öğrenciler ise yaşanan çatışmaları fakülte dışında alınan din eğitimine bağlamıştır. Bu öğrencilerden biri olan Burak, fikirlerini şu sözlerle dile getirmiştir: "Öğrenci buraya; farklı bir bilgiyle, donanımla geliyor. İmam hatipte aldığı bilgi var, sosyal medyadan bazı hocalardan edindiği donanımlar var. Öğrenci, o donanımlarla buraya gelince, burada olan farklı görüşlerle çatışıyor. Burası biraz daha eleştirel, sonuçta üniversiteden bahsediyoruz, akademiden bahsediyoruz. Eleştirel olunca öğrenciler direkt önyargıyla bakıyor. Bunun sonucunda da önyargıyla bakan kişiler kendi arasında çatışıyor." Bilecik'in ${ }^{90}$ araştırmasına katılan öğrencilerin çoğu da fakülte dışında din eğitimi aldığını belirtmiştir. Bu durumla yenilikçi bakış arasında anlamlı ilişki olduğuna dikkat çeken Bilecik, fakülte dışında alınan din eğitiminin öğrencilerin daha gelenekçi olmasına yol açtığını tespit etmiştir. $\mathrm{Bu}$ veriler, öğrencilerin fakülte dışında aldıkları din eğitimiyle fakültede aldıkları din eğitiminin hem öğrencinin iç dünyasında hem de diğer öğrencilerle çatışma yaşamasında etkili olabileceğini göstermektedir.

Öğrencilerin bir kısmı, ilahiyat eğitimiyle çatışma ilişkisini hocaların uzmanlık alanlarına dikkat çekerek ifade etmiştir. Konuya bu perspektiften yaklaşan

87 Bkz. Abdulvehap Boz, “Öğretim Elemanlarının İstenmeyen Davranışları İle Öğrenci Yabancılaşması Arasındaki İlişki”, Pamukkale Üniversitesi Eğitim Fakültesi Dergisi, 2020, $1-26$.

88 Kurtman Ersanl1, “Ortaöğretimde Öğretmen-Öğrenci İlişkilerinin Dayandığı Temeller”, Ondokuz Mayls Üniversitesi Eğitim Fakültesi Dergisi 4/1 (2014): 40-44.

89 Ahmet Koç, "İlâhiyat Fakültesi (İlâhiyat Lisans Programı) Öğrencilerinin Sorunları ve Beklentileri”, Marmara Üniversitesi Illahiyat Fakültesi Dergisi 25, sy 2 (2003): 41-42.

90 Sümeyra Bilecik, "İlahiyat Fakültesi Öğrencilerinin Dinde Yenilikçiliğe Bakış Açıları ve Eleştirel Düşünme Eğilimi İlişsisi (NEÜ İlahiyat Fakültesi Örneği)”, Marife Dini Araştırmalar Dergisi 19, sy 2 (2019): 312-13. 
öğrencilerden biri Reyhan'dır: "Dersler kendi aralarında çatışmaya şöyle müsait; ders ne olursa olsun bunu, insan okuyor ve insan anlıyor. Hoca etkili, çatışmaya sebep oluyor, ama ben bu hoca olmadan kelam ve hadisi kendim okusaydım ya da bu metinler üzerinde kendim uzmanlaşmış olsaydım, yine bunları çatıştırırdım." Benzer şekilde Tokat ${ }^{91}$ da çatışmanın nedenlerinden biri olarak uzmanlık alanlarını göstermiştir. İlahiyat fakültelerinin akademik yapılanmasına bakıldığında da gerek bölümler arasında gerekse anabilim dallarının kendi içerisinde ayrıntılı branşlaşmaya gidildiği görülmektedir. Bu konuda özellikle TİB bölümündeki alanların çatışmaya yol açma potansiyellerinin daha yüksek olduğu söylenebilir. Zira bu bölümdeki alanlar; iman, ibadet, ahlak, muamelat gibi bütün temel dinî konuları ele alır ki bu konuların önemli bir kısmı tartışmaya müsaittir. Eğer bu konular değerlendirilirken dışlayıcı bir perspektif sergilenirse, çatışmanın çıkması da kaçınılmaz olacaktır.

Son kategoride ilahiyat eğitiminin çatışmaların çözümüne etkisi üzerinde durulmuştur. Öğrencilerin çoğu, bir yandan aldığı lisans eğitiminin çatışmaya neden olduğunu belirtmesine rağmen, diğer yandan bu eğitimin bazı çatışmaların çözümüne katkı sağladığını da ifade etmiştir. Bu durum, bir çelişki gibi görünmektedir. Mesela Feride, kelam ve hadis dersleri üzerinden konuyu şöyle değerlendirmiştir: "Bence kelam ve hadis dersleri ayrı ayrı anlatılırken ikisi de çatışmanın çözümüne katkı sağlıyor, ama birbiriyle atıyorum sen hadisçisin ben kelamcıyım gibi bir şey olunca arada bir kopma olabiliyor." Burada üzerinde durulması gereken nokta, öğrencilerin her iki husustaki görüşlerini hocalar, farklı fikirler, kişisel özellikler gibi birtakım potansiyel durumları göz önüne alarak kayıtlamalarıdır. Söz gelimi bir hocadan hareketle bir dersin çatışma çıkarmada etkili olduğunu söyleyen öğrenci, diğer hocayı dikkat aldığında aynı dersin çatışmaların çözümündeki belirleyiciliğinden bahsetmiş olmaktadır.

\section{Empati}

Bireylerin dinî uzlaşma anlayışı ve kültürüne sahip olması için muhatabıyla empati kurması ve iletişime geçmesi önemlidir. Bu alt yapıyla şekillenen ilişkilerde uzlaşma imkânı artacaktır. Buradan hareketle üçüncü temada ilahiyat eğitiminin öğrencilerin empati ve iletişim becerilerine katkı sağlama durumu ele alınmış ve gelen cevaplar dört kategoride tasnif edilmiştir.

İlk kategoride öğrencilerin diyaloglardaki üslupları ve ilahiyat eğitiminin bu duruma etkisi irdelenmiştir. Öğrencilerin çoğu, ilahiyat eğitiminin empati kurmaya katkı sağladığını belirtirken; bu hususta kelam, İslam mezhepleri tarihi,

91 Bülent Tokat, “Örgütlerde Çatışma ve Çatışmanın Yönetimi”, Dumlupınar Üniversitesi Sosyal Bilimler Dergisi, sy 1 (1999): 28-29. 
din sosyolojisi, din psikolojisi, dinler tarihi ve formasyon derslerinin etkili olduğuna işaret etmiştir. Bu öğrencilerden biri olan Selim, düşüncelerini şu şekilde dile getirmiştir: "Fakülteye ilk girdiğim zamanlarda daha çok reddetme taraftarıydım. Ama sonlara doğru hem okumalarımız hem de hocalarımızla belli bir olgunluğa eriştik. Dolayısıyla ilk önce meseleyi anlama taraftarı oluyoruz, ondan sonra çözüme dair neler yapabileceğimizi düşünmeye başliyoruz. Bu hususta en çok kelam, din sosyolojisi ve din psikolojisi dersleri katkı sağladı." Öğrencilerin bir kısmı ise özellikle hadis ve Kur'an-1 Kerim gibi ezber odaklı işlenen derslerin empati konusunda etkisiz olduğuna değinmiştir. Örneğin Reyhan, bu konuda şunları söylemiştir: "Kur' an-1 Kerim ve Arapça gibi ezber odaklı dersler haricinde diğer dersler, biraz daha pozitif olan dersler bence anlamaya yönelik katkı sağlıyor." Ayrıca TİB alanına ait tefsir, kelam, hadis gibi derslerin antipatiye neden olduğuna yönelik öğrenci görüşleri bulunurken, kimisi bu durumun müsebbibi olarak hocaları göstermiş, kimisi de bu durumdan dersleri mesul tutmuştur. FDB alanındaki din sosyolojisi, din psikolojisi, din eğitimi ve ayrıca formasyon derslerinin empati kurmaya katkı sağladığına yönelik öğrenci görüşlerinde ise ortak kanaatin olduğu görülmüştür.

Öğrencilerin bu bahiste ele alınan sempati kavramını, ${ }^{92}$ literal anlamının dışında daha olumlu bir mana yükleyerek, empatiyle birlikte değerlendirdikleri; buna karşın antipati kavramını literal anlamı doğrultusunda kullandıkları görülmüştür. $\mathrm{Bu}$ öğrencilerden biri olan Pelin, aldığı ilahiyat eğitiminin genel anlamda empati ve sempati kazandırdığının altını çizmiştir: "İlahiyat eğitimi anlamaya ve hak vermeye katkı sağladı. Çünkü çok fazla insan gördüğün için onun neden öyle düşündüğünü daha farklı düşüncelere neden sahip olduğunu anlıyorsun ve hak veriyorsun." Kur'an-1 Kerim'den hareketle empati ve sempati kavramlarını ele alan Kasapoğlu ${ }^{93}$ da bir taraftan çeşitli ayetler ${ }^{94}$ doğrultusunda Kur'an-1 Kerim'in insanları empatiye yönlendirdiğini vurgulamış, diğer taraftan Hz. Peygamberin kişiliğiyle ilgili ayetler ${ }^{95} 1$ şığında sempatik davranışların varlığına işaret etmiştir. Bu doğrultuda öğrencilerin sempatiye yaklaşımları, dinî inançlarının bir yansıması olarak değerlendirilebilir.

İkinci kategoride ise ilahiyat eğitimiyle empati arasındaki ilişkiye yer verilmiştir. Öğrencilerin büyük bir kısmı, ilahiyat eğitiminin empati noktasında olumlu katkı sağladiğını söylemiştir. Bu şekilde düşünen öğrencilerden biri olan Ayşe, süreç

92 Krş. Tarhan, Toplum Psikolojisi ve Empati Sosyal Şizofreniden Toplumsal Empatiye, 162-63.

93 Bkz. Abdurrahman Kasapoğlu, "Empati ve Sempati Olgusuna Vurgu Yapan Bazı Ayetler", Bilimname, sy 1 (2006): 44-60.

94 Âl-i İmrân 3/92, Bakara 2/267, Duhâ 3/6-10.

95 Tevbe $9 / 128$. 
içerisinde empati becerisinin geliştiğini vurgulamıştır: "İlahiyattan önce ve sonra diye iki dönemim olduğunu düşünüyorum. İlahiyattan önce pek empati kuramazdım, çünkü dik kafalı bir düşünce yapısına sahiptim, ilahiyattan sonra artık empati kurabiliyorum." Koç'un ${ }^{96}$ araştırmasındaki öğrencilerin çoğu da kendinden farklı düşünen muhatabına hoşgörüyle yaklaştı̆ıını belirtmiştir. Hoşgörü, empati kurmayı kolaylaştıracağı için bu durum öğrencilerin empati becerilerinin bir göstergesi olarak değerlendirilebilir.

Görüşme yapılan öğrencilerin önceki kategoride hadis, kelam, tefsir gibi derslerin antipatiye neden olduğunu belirtmelerine rağmen, bu kategoride bahsi geçen derslerin empatiye de katkı sağladığını ifade etmeleri, çelişkili bir durum gibi algılanabilir. Buradaki ikilemin nedeni, öğrencilerin fikirlerini hocalar üzerinden dile getirmeleridir. Örneğin Hasan, ilahiyat eğitimi süresince empati becerisi kazanma noktasında derslerin ve hocaların etkili olduğuna dikkat çekmiştir: "İlahiyat fakültesine ilk geldiğimizde, karşı tarafı anlamadan, empati kurmadan, kendi fikirlerimizi empoze etmeye çalışıyorduk. Ama ilerleyen süreçte hem dersler hem de hocalar bize eleştirel düşünmeyi, sorgulamayı, empati kurmayı öğretti. ... Bu konuda özel olarak kelam, hadis, din eğitimi, din sosyolojisi, din psikolojisi dersleri ve hocaları etkili oldu.” Bu tenakuzun giderilmesi için hocalarla öğrenciler arasında etkili iletişimin kurulması gerekirken, bu konuda empatinin ${ }^{97}$ önemli bir faktör olduğu söylenebilir. TİB alanındaki bu derslere karşın öğrencilerin geneli; din sosyolojisi, din psikolojisi, din eğitimi, dinler tarihi derslerini empatiye katk1 sağlayan dersler arasına yerleştirmiştir. Öğrencilerin bir kısmı ise empatinin kendi karakterlerinde olduğunu söylerken, ilahiyat eğitimin bilgi edindirme noktasında empati becerisi kazandırmaya katkı sağladığını ifade etmiştir. Öğrencilerden biri (Kadir), bu konuda şunları dile getirmiştir: "Empati, bence okulla alakası olmayan, insanın kendinde olan bir şeydir. Bende önceden beri olduğunu düşünüyorum, okulun bir etkisi olduğunu düşünmüyorum. Ama bilgiyle empati birleştirilince seviyenin biraz arttığını ve karşı tarafın da farklı yorumlarına güzellikle yaklaşmamızı sağladığını düşünüyorum." Öğrencilerin bu savını destekleyecek şekilde Kasapoğlu, ${ }^{98}$ da empatinin insanlarda potansiyel halinde bulunabileceğine işaret ederken, eğitimle bu potansiyelin gelişeceğini vurgulamıştır.

Eğitim bir iletişim süreci olarak değerlendirildiği için üçüncü kategoride ilahiyat eğitiminin, iletişim becerisine etkisi ele alınmıştır. Öğrencilerin çoğu, derslerin

96 Koç, "İlâhiyat Fakültesi (İlâhiyat Lisans Programı) Öğrencilerinin Sorunları ve Beklentileri”, 51-52.

97 Ali Rıza Aydın, “Öğretmen-Öğrenci İlişkilerinde Empati ve Öğretmenlerin Rol Modelliği Üzerine”, Dinbilimleri Akademik Araştırma Dergisi 9, sy 4 (2009): 75-78.

Kasapoğlu, "Empati ve Sempati Olgusuna Vurgu Yapan Bazı Ayetler”, 36-37. 
iletişim konusunda belirleyici olduğunu düşünürken; çok az bir kısmı, bu husustaki yükümlülüğü hocalara havale etmiş ve empati kategorisindeki gibi bu hususta da din sosyolojisi, din psikolojisi, din eğitimi, dinler tarihi ve formasyon derslerinin katkı sağladığını ifade etmiştir. Örneğin Derya, derslerin iletişim kurma hususunda olumlu etkiye sahip olduğunu belirtmiştir: "Derslerin iletişime katkı sağladığını düşünüyorum. Özellikle formasyon dersleri bence çok etki ediyor. Ayrıca din eğitimi, din psikolojisi dersleri de iletişime girmede katkı sağlıyor." Selim ise derslerin iletişim kurmaya katkısının olabileceğini söylerken, hocalar devreye girdiğinde işin renginin değiştiğini ifade etmiştir: "Ders noktasında yardımcı olur, ama burada hoca faktörü devreye girdiği için bundan söz etmek pek mümkün olmuyor. Gelenekçi damardan gelen biri karşısındaki insanı direkt günahkâr olarak gördüğü için onu oturup anlamaya çalışmıyor, ona direkt kendi bildiği doğruyu, hakikat olarak dayatma çabasına giriyor, onun için pek hoşgörüden bahsedilmez. Bu nedenle de iletişim kurmada olumsuz etki ediyor."

Araştırma verilerini destekler şekilde Arıcı ve Angın ${ }^{99}$ da araştırmalarına katılan ilahiyat öğrencilerinin iletişim beceri düzeylerinin yüksek olduğu sonucuna varmışlardır. Aynı şekilde $\mathrm{Akyol}^{100}$ da yaptığı araştırmayla ilahiyat öğrencilerinin iletişim beceri düzeylerinin yüksek olduğu neticesine ulaşmıştır. Bu konuda görüşme yapılan birçok öğrencinin kelam dersinin öteki, çatışma, empati gibi konularda olumsuz etki gösterdiğini belirtmesine karşın iletişim konusunda katkı sağladığını vurgulaması dikkat çekicidir.

Sınıf ortamı, ilahiyat eğitimiyle geliştirileceği düşünülen empati ve iletişim becerilerinin bir nevi uygulama sahası olarak değerlendirilebilir. Bu nedenle dördüncü kategoride, öğrencilerin ders esnasında hocayla muhalif düşüncelerini ifade etme durumu sorgulanmıştır. Öğrencilerin çoğu, bu durumun hocalara göre değişeceğine işaret ederken bu konuda tefsir, kelam, hadis ve İslam hukuku derslerinin isimlerini zikretmiş ve bu derslerde sınıf arkadaşlarının da daha farklı bir tutuma sahip olduklarının altını çizmiştir. Bunun aksine öğrenciler; din eğitimi, din psikolojisi, din sosyolojisi ve dinler tarihi derslerinde ise ciddi bir sıkıntı yaşamadıklarını belirtmişlerdir. Öğrencilerden biri (Ayla), bu konudaki fikirlerini şu şekilde dile getirmiştir: "Dersine göre değişiyor. Bir kere hadiste farklı düşünceye pek yer vermiyorlar. Tefsir dersinde kısmen, o da hocasına göre değişiyor. İslam hukukunda da çok değil. Kelam dersinde yine tartışma konusu olduğu için daha çok dile getirebiliyorsun. İslam mezhepleri tarihi, dile

99 Bkz. İsmail Arıcı ve Yasemin Nakşiye Angın, "İlahiyat Fakültesi Öğrencilerinin İletişim Beceri Düzeyleri”, Amasya Üniversitesi Illahiyat Fakültesi Dergisi, sy 8 (2017): 199-219.

100 Pelin Akyol, “Farklı Fakültelerdeki Öğrencilerin İletişim Becerilerinin Karşılaştırılması”, Spor Ĕ̈itim Dergisi 3, sy 3 (2019): 71-77. 
getirebiliyoruz. Din eğitimi, din psikolojisi, din sosyolojisi bunlar toplumbilimi oldukları için bir yere kadar yorum yapabiliyorsun. Felsefe derslerinde de yorum ve farklı fikir yok." Bu durumun sebebi olarak TiB ve FDB alanına ait ders içerikleri gösterilebilir. Zira TİB alanına ait dersler dinin temel kaynaklarına dayandığ için öğrenciler bu dersleri alan dersleri olarak görmekte ve hocaların ya da arkadaşlarının yorumlarını kendi dinî fikirleri bağlamında değerlendirerek tutum belirlemektedirler. Buna karşın, FDB derslerini destekleyici dersler kapsamında ele aldıkları için bu derslerdeki düşünce farklılıklarını dinî görüşleri üzerinden yorumlama ihtiyacı hissetmemektedirler.

Eğitimi bir iletişim süreci olarak değerlendiren Çakmak ve Aktan, ${ }^{101}$ okul ortamında iletişimin niteliğini belirleyen en önemli unsur olarak öğretmeni görürken, öğretmen ve öğrencinin iletişim sürecindeki tutumlarının çok önemli olduğuna işaret etmişlerdir. Benzer şekilde Kaya, Çiftçi ve Özdemir ${ }^{102}$ de öğretmen-öğrenci iletişiminin düzgün bir işleyişe sahip olması için öğretmeni ön plana çıkarmış ve öğretmenin öğrenciyle iletişim kurarken; onun fikirlerine saygı duymak, bir fikirde ısrarcı olmamak, öğrenciyle empati kurmak gibi unsurlara dikkat etmesini gerekli görmüşlerdir. Bayrakdar' $1 \mathrm{n}^{103}$ araştırmasındaki öğrencilerin düşünmeye, eleştirmeye, sorgulamaya, araştırmaya, kendi fikirlerini ifade etmeye firsat veren hocaların derslerinde kendilerini daha rahat hissettiklerini belirtmeleri de bu savı destekler niteliktedir. Koç, ${ }^{104}$ buna paralel olarak kaynak ve alıcının birbirlerini anlamamaları, birbirlerine saygı duymamaları gibi hususları iletişim engeli olarak sıralarken; Tetik ${ }^{105}$ de bu bağlamda kutuplaşma, önyargı, genelleme vs. faktörlere yer vermiştir. Ergin ve Geçer' in ${ }^{106}$ araştırmasındaki öğrencilerin, hocaların iletişim esnasında öğrencileri kendileriyle eşit görmediklerini belirtmeleri de önemli iletişim engellerinden biridir. Nitekim görüşme yapılan öğrenciler de sınıf ortamında

101 Veysel Çakmak ve Ercan Aktan, "Öğretmen Öğrenci İletişiminin Çeşitli Değiş̧kenlere Göre İncelenmesi”, Elektronik Sosyal Bilimler Dergisi 15, sy 56 (2016): 84-89.

102 Mehmet Tamer Kaya, Barış Çiftçi, ve Abdullah Gökdemir, "Sosyal Bilgiler Öğretmen Adaylarının İletişim Becerilerinin Çeşitli Değişkenler Açısından İncelenmesi”, International Primary Education Research Journal 3, sy 1 (2019): 32-33.

103 Nazım Bayrakdar, "İslami İlimler Fakültesi Öğrencilerine Göre Derslere Yönelik Olumlu Tutum Geliştirmelerine Katkı Sağlayan Öğretim Elemanı Davranışları”, Insan ve Toplum Bilimleri Araştırmaları Dergisi 5, sy 8 (2016): 3042-51.

104 Bkz. Ahmet Koç, Din Eğitiminde Etkili İletişim (İstanbul: Rağbet Yayınları, 2016), 243-249; Ayrıca iletişim temel prensipleri için bkz. Mustafa Köylü, Psiko-Sosyal Açıdan Dini İletişim (Samsun: Ondokuz Mayıs Üniversitesi, Sosyal Bilimler Enstitüsü, Doktora Tezi, 2002), 44-94.

105 Bkz. Hayati Tetik, "Din Hizmetlerinde İletişim Becerileri ve Empati”, EKEV Akademi Dergisi, sy 41 (2009): 159-82.

106 Akif Ergin ve Aynur Geçer, “Öğrenci Algılarına Göre Öğretim Elemanlarının İletişim Biçimleri”, Ankara Üniversitesi Ĕ̈itim Bilimleri Fakültesi Dergisi 41, sy 2 (2008): 7-9. 
muhalif fikirlerini dile getiremeyeceğini düşündükleri hocalarda bahsedilen bu vasıfların olduğunu belirtirken, sıralanan olumlu vasıflara sahip hocaların derslerinde ise fikirlerini rahatça söyleyebileceklerini ifade etmişlerdir. Ayrıca Erpay' $1 n^{107}$ araştırmasında olduğu gibi bu araştırmada da imam hatip lisesi mezunu olmayan öğrencilerin ilahiyat ortamını daha baskıcı buldukları görülmüştür.

\section{Uzlaşma}

Dinî uzlaşma anlayışı ve kültürü aynı toplumda yaşayan fertlerin bir arada huzur ve güven içerisinde hayatlarını idame ettirebilmeleri için gereken unsurlardandır. $\mathrm{Bu}$ unsurların toplumda karşılık bulması için din ve eğitim gibi alanlara birtakım görevler düşer. Buradan hareketle ilahiyat eğitimiyle dinî uzlaşma kültürü arasındaki ilişkinin ele alındığı son tema, beş kategoriden oluşmuştur.

İlk kategoride öğrencilerin uzlaşma tanımlarına yer verilmiş ve bu tanımların ortak noktaya varma, anlaşma ve hoşgörü şeklinde üç alt kategoriye ayrıldığ 1 görülmüştür. Örneğin Ali, ortak noktayı merkeze alarak uzlaşmayı "Birbirinden farklı ya da birbirine zıt iki düşüncenin ya da kişinin orta yolu bulması, ortak bir noktada buluşması" şeklinde açıklarken; Cihan, anlaşmaya odaklanarak kavramı "İki kişinin ya da toplumun birbiriyle olan ilişkilerinin anlaşılabilir hâle getirilmesi için gerekli olan şey” olarak tanımlamış; Burak ise kavramı hoşgörü ekseninde ele almıştır: "Uzlaşma; insanların birbirine hoşgörüyle bakması, farklı görüşlere sayg1 göstermesidir.” Literatür incelendiğinde benzer şekilde Türer'in ${ }^{108}$ de uzlaşmanın farklılıklardan kaynaklandığını vurguladığı ve uzlaşmayı bu farklılıkların ortak noktada buluşması olarak değerlendirdiği anlaşılmaktadır.

Ehl-i Sünnet geleneğinin baskın olduğu ilahiyat eğitiminin uzlaşmayla bağlantısını derinlemesine inceleyebilmek maksadıyla ikinci kategoride İslam ve uzlaşma ilişkisi ele alınmıştır. Öğrencilerin İslam'daki uzlaşma anlayışına yönelik görüşleriyle ilahiyat eğitiminden beklentileri ve bu eğitimin kendilerine kazandırdıklarına ilişkin ifadelerinin orantılı olması beklenir. Bu bağlamda görüşme yapılan öğrencilerin çoğunun hem uzlaşmayı tanımlarken hem de İslam ve uzlaşma ilişkisini değerlendirirken hoşgörü, saygı, iletişim gibi kavramların önemine dikkat çektiği görülmüştür. Teoride bu fikirlerin olduğunu düşünen Beyza, uygulama noktasında birtakım sıkıntıların olduğuna dikkat çekmiştir: “Kur'an-1 Kerim ve sünnete göre Müslümanlar tek bir vücut olmalı bence ve

107 İlyas Erpay, “Öğrencilerin İlahiyat Fakültesine Yönelik Görüşleri”, Amasya İlahiyat Dergisi, 13 (2019): 441-444.

108 Detaylı bilgi için bkz. Celal Türer, "Uzlaşma/nın Felsefesi”, Ombudsman Akademik, sy 4 (2016): 171-88. 
tek vücut olmak için uzlaşmak gerekir. Sonuçta hepimize gönderilmiş olan tek bir din var ve bizim bu dinin etrafında uzlaşmamız gerekir. O yüzden İslam dini uzlaşmayı bize emrediyor, ama biz kendi içimizde, herkes kendine göre bir grup oluşturuyor, o grubun altında hayatını idame ettirmeye çalışıyor ve bu yüzden uzlaşamıyoruz." Ayşe ise hem teoride hem de pratikte uzlaşmanın olması gerektiğini dile getirmiştir: "Dönem dönem farklı fikirler ortaya çıkıyor ve İslam farklı fikirde olanların çatışmamalarını istiyor. Ortak bir fikirde uzlaşmalarını istiyor, başka bir şey istemiyor.” Buradan hareketle öğrencilerin kendilerinde ve arkadaşlarında bu niteliklerin olmasını istedikleri sonucuna varılabilir. Nitekim Osmanoğlu ve Korkmaz' $1 n^{109}$ araştırmasındaki öğrenciler de saygı, hoşgörü, iletişim, empati gibi vasıfların ilahiyat öğrencisinde bulunmasını elzem gördüklerini belirtmişlerdir.

Bir konuya farklı pencereden bakarak ortak bir zeminde buluşma fırsatı sunan uzlaşmaya kapı aralayacak önemli etkenlerden biri de yorum yapmaktır. Bu duruma binaen üçüncü kategoride ilahiyat eğitimiyle yorum yapma ilişkisine yer verilmiş̧ir. Öğrencilerin çoğu, hocaları göz önünde bulundurarak yorum yapma fırsatının değişkenlik gösterdiğini ifade ederken; bu hususta hadis, tefsir, kelam, İslam hukuku ve felsefe derslerinin isimlerini zikretmişlerdir. Buna karşın İslam tarihi, İslam mezhepleri tarihi, din sosyolojisi, din eğitimi, din psikolojisi, dinler tarihi ve formasyon dersleriyle hocalarının yorum yapmaya imkân tanıdığını söylemişlerdir. Örneğin Ayla, bu konudaki fikirlerini şu şekilde dile getirmiştir: "Kelam derslerinde hocasına göre yoruma açık verildi, hocasına göre yoruma açık verilmedi. Felsefe, hocasına göre değişebiliyor. Tefsir, hocasına göre değişebiliyor. İslam hukuku dersinde hoca yoruma pek açmadı, açsaydı açılabilirdi."

Taşkıran' $1 n^{110}$ araştırmasına katılan öğrencilerin çoğu da FDB alanındaki derslerin dinî metinlerin yorumlanmasına katkı sağladığını dile getirmiştir. Benzer şekilde Çinemre'nin ${ }^{111}$ çalışmasında da programın işlevselliği hakkında üzerinde durulan yeni bakış açıları kazandırma, problemlere karşı çözüm üretme, bireyin gelişimini sağlama gibi hususlar, öğrencilere farklı bakış açılarına sahip olma ve yorum yapma firsatı sunacak niteliktedir. Fakat neredeyse tüm öğrencilerin bu mevzuyu daha ziyade hocalar üzerinden değerlendirdiği unutulmamalıdır. Bu doğrultuda

109 Bkz. Cemil Osmanoğlu ve Mehmet Korkmaz, “Öğrencilerine Göre İdeal İlahiyat Fakültesi Öğrencisinin Nitelikleri ve Bunun İlahiyat Eğitimiyle İliş̧kisi”, Değerler Ĕgitimi Dergisi 16, sy 36 (2018): 128-34.

110 Taşkıran, "İlahiyat Fakültesi Müfredatında Felsefe ve Din Bilimleri Bölümü Derslerinin Yeri ve Fonksiyonlarına Dair Bir Araştırma (İlahiyat Fakültesi Öğrencileri Örneği)”, 256-58.

111 Semra Çinemre, "İlahiyat Fakültesi Son Sınıf Öğrencilerinin İlahiyat Fakültesi Programına İlişkin Algılarının Metafor Analizi Yoluyla İncelenmesi”, İlahiyat Tetkikleri Dergisi, sy 52 (2019): 279-80. 
İslam eğitim tarihinde görülen hocanın dersteki hâkimiyetinin ve hoca-öğrenci ilişkilerinin ${ }^{112}$ ilahiyat fakültelerinde hâlâ devam ettiği ifade edilebilir.

Hem Yeğin'in ${ }^{113}$ hem de Bilecik'in ${ }^{114}$ yenilikçilik üzerine yaptıkları araştırmalardaki öğrencilerin çoğunun kendini yenilikçi olarak tanımlamaları, bu araştırmadaki öğrencilerin lisans eğitiminin genel anlamda yorum yapmaya imkân sağladığını belirtmeleriyle örtüşmektedir. Çünkü uzlaşmanın gerçekleşmesi için gereken unsurlar arasında sayılabilecek yorum yapmak, yeniliklere ve değişikliklere açık olmayla bağlantılıdır.

Müfredat, hoca ve sınıf ortamı öğrencilerin dinî uzlaşma anlayışı kazanmasında kritik konumda olduğu için dördüncü kategoride ilahiyat eğitimi uzlaşma ilişkisi ele alınmıştır. Öğrencilerin çoğunun din sosyolojisi, din psikolojisi, din eğitimi, dinler tarihi, formasyon dersleri ve hocalarının uzlaşmaya katkı sağladığı konusunda hemfikir olduğu görülürken; hadis, tefsir, kelam ve İslam hukuku gibi derslere dair farklı fikirler serdettiği dikkat çekmiştir. Bu farklılaşmanın nedeni, İslam anlayışının merkezde olduğu bu fakültede TİB bölümündeki derslerin alan dersleri, FDB derslerinin destekleyici dersler olarak değerlendirilmesi ve öğrencilerin kendilerini yakın hissettikleri alan ve hocaların değişiklik göstermesidir. Örneğin Kadir, bu konuya şu şekilde açılık getirmiştir: "Din eğitimi, din psikolojisi, din sosyolojisinde uzlaşma var, ama onlar hakkında pek bir şey söyleyemiyorum. Çünkü bu dersler ilişki dersleri bence. Onlar da kesin etkili, ama benim için pek önemli değil. ... Arap dili ve belagatı uzlaşma sağlıyor. Tefsir yorumlamamızı sağlıyor. Hadis de İslam'ın yöntemi, şekli olduğu için ona da ihtiyaç var. İslam hukuku da etkili. Dinler tarihi kısmen önemli. İslam tarihi de bilgi açısından önemli. Türk dini musikisi insanlara daha güzel, hoş yaklaşabilmemiz için önemli. Kelam da düşünceyi sağlıyor.” Kadir'den farklı olarak Yavuz, derslerle ilgili şunları söylemiş̧tir: “Kur'an-1 Kerim, Arap dili ve belagatı açıkçası bizim düşünce olarak değil, daha çok ezber ve konuşma üzerine eğitim aldığımız dersler ve bu nedenle uzlaşmaya çok fazla etkisi olduğunu düşünmüyorum. Tefsir, kelam, tasavvufun biraz etkisi var. Hadisin kısmen etkisi var. Din eğitimi, din sosyolojisi,

112 İslam eğitim geleneğinde öğretmen ve öğrenciyle ilgili bkz. Mehmet Faruk Bayraktar, İslam Ĕgitiminde Öğretmen-Öğrenci Münasebetleri (İstanbul: Marmara Üniversitesi İlahiyat Fakültesi Vakfı Yayınları, 2018); Muhammet Şevki Aydın, "İslam Eğitim Geleneğinde Öğretmenlik", Erciyes Üniversitesi İlahiyat Fakültesi Dergisi, sy 11 (2001): 59-74; Bayramali Nazıroğlu, İslam Ĕ̆itim Geleneğinde Öğretmenlik (Ankara: Sarkaç Yayınları, 2011); Mustafa Köylü ve Ahmet Koç, ed., Klasik Íslam Eğitimcileri (İstanbul: Rağbet Yayınları, 2016).

113 Hüseyin İbrahim Yeğin, "İlahiyat Fakültesi Öğrencilerinin Bireysel Yenilikçilik Düzeyleri”, AIBB̈̈ Sosyal Bilimler Enstitüsü Dergisi 17, sy 4 (2017): 253.

114 Bilecik, "İlahiyat Fakültesi Öğrencilerinin Dinde Yenilikçiliğe Bakış Açıları ve Eleştirel Düşünme Eğilimi İlişkisi (NEÜ İlahiyat Fakültesi Örneği)”, 303-5. 
din psikolojisi dersleri uzlaşma konusunda katkı sağlıyor.” Buradan hareketle öğrencilerin kendini yakın hissettikleri TİB dersleri ve hocalarının uzlaşmaya katkı sağladığını, benzer fikirlere sahip olmayan ders ve hocaların ise uzlaşma konusunda etkisiz olduğunu ifade ettikleri sonucuna varılabilir. Söz gelimi kabir azabı konusu TİB bölümündeki farklı derslerde ele alınabilirken, hocalar da konuyu farklı perspektiflerden değerlendirebilirler. Bundan ötürü öğrenciler de hocaların bu gibi dinî mevzulardaki kanaatlerinden yola çıarak, dersler ve hocalarla ilgili sübjektif kanaatler geliştirebilirler. Buna karşın FDB derslerinde bu gibi tartışmalı dinî konular doğrudan ele alınmadığı için öğrenciler, bu alandaki ders ve hocaları daha objektif bir şekilde değerlendirebilmektedirler.

Görüşme yapılan öğrencilerin çoğunun, lisans eğitiminin uzlaşmaya katkısını eleştirel düşünme, iletişim, ötekileştirmeme gibi olgulardan hareketle ele aldığ 1 dikkat çekmiştir. Nitekim bu durum, Osmanoğlu ve Korkmaz' ${ }^{115}$ araştırmasındaki katılımcıların ilahiyat öğrencisinde bulunmasını gerekli gördüğü yeni ve farklı fikirlere açık olma, eleştirel bakabilme, bilgisini güncelleyebilme gibi vasıflarla örtüşmektedir. Ancak Uçar'ın ${ }^{116}$ araştırma verilerinde hocaların ders işleme metodu, aktif katılımı sağlama, iletişim vb. konularda yetersiz kaldığ için eleştirel düşünmeyi geliştirmediğine ve farklılıklara açık olunmadığına işaret etmesi, araştırma verilerimizle tam olarak denk düşmemektedir. Zira görüşülen öğrencilerin çoğu, hocaların bu konuda kendilerine katkı sağladığını belirtmiştir.

İlahiyat eğitiminin öğrencilerin bireysel uzlaşma anlayışlarına etkisinin ele alındığı son kategoride, öğrencilerin büyük bir kısmı lisans eğitiminin uzlaşma anlayışlarını geliştirdiğini ifade ederken, az bir kısmı bu konuda birkaç dersin katkı sağlamadığına dikkat çekmiştir. Öğrencilerin çoğu, bu hususta kelam, din sosyolojisi, din psikolojisi, din eğitimi, felsefe, İslam mezhepleri tarihi, İslam tarihi derslerinin katkısından bahsederken; az bir kısmı tefsir ve İslam hukuku derslerinin de etkili olduğunu söylemiştir. Örneğin Beyza, bu konuda tefsir, kelam gibi dersleri ön plana çıkarmıştır: "Ben fakülteye gelmeden önce çok önyargılı bir insan olduğumu düşünüyorum. Şu anda da önyargılarım vardır muhakkak, ama beş yıl önceki kadar değildir. Çünkü tartabiliyorum, artık insanın ilk görünüşteki gibi olmayacağını biliyorum. Bu hususta tefsir, kelam ve İslam mezhepleri tarihi derslerinin belirleyici olduğunu düşünüyorum.” Ömer ise bu konuda FDB derslerinin de önemli olduğunu vurgulamıştır: "Bu okul bana kelam, İslam mezhepleri tarihi,

115 Osmanoğlu ve Korkmaz, “Öğrencilerine Göre İdeal İlahiyat Fakültesi Öğrencisinin Nitelikleri ve Bunun İlahiyat Eğitimiyle İlişkisi”, 134-38.

116 Bkz. Recep Uçar, “İlahiyat Fakültesi Öğrencilerinin Profili, Akademik Eğilimleri ve Aldıkları Eğitime İlişkin Memnuniyet Algıları (İnönü Üniversitesi Örneği)", İn̈nü Üniversitesi İlahiyat Fakültesi Dergisi 8, sy 2 (2017): 154-64. 
dinler tarihi, din eğitimi, din psikolojisi, din sosyolojisi gibi derslerle uzlaşının zeminini verdi."

Örnekleminde RTEÜ İlahiyat Fakültesinin de bulunduğu Osmanoğlu'nun ${ }^{117}$ araştırmasındaki katılımcıların çoğu; ötekileştirme, gruplaşma, iletişim sorunları, farklılıklara bakışın sıkıntılı olması gibi nedenlerden ötürü kendilerini ilahiyat ortamına ara sıra yabancı hissettiklerini belirtirken; aynı zamanda bu gerekçeleri dayatmac1, tutucu, sorgulamaya kapalı, kalıplayıc1, farkl11ıklara kapalı, ön yargıl1 ve dışlayıcı olma ${ }^{118}$ unsurlarıyla detaylandırmış ve bu konuda alan derslerinin belirleyici olduğuna dikkat çekmiştir. Zikredilen bu faktörler uzlaşmaya engel teşkil ederken, görüşme yapılan öğrenciler de bu gibi durumlarla alan derslerinde karşılaştıklarını ifade etmişlerdir. Buna karşın öğrencilerin hemen hepsi, ilahiyat eğitiminin genel anlamda uzlaşma, empati ve iletişim becerilerini geliştirdiğini dile getirmiştir. Nitekim Taştan, Kuşat ve Çelik' in ${ }^{119}$ araştırmasındaki öğrencilerin çoğunun ilahiyat eğitiminin bilgi, düşünce ve davranış değişikliğine katkı sağladığını vurgularken, bu katkının eleştirel düşünme, farklılıklara saygı duyma, hoşgörülü olma gibi vasıflarla kazandırıldığına dikkat çekmeleri, bu araştırmanın verileriyle orantılıdır. Benzer şekilde Tosun'un ${ }^{120}$ araştırmasındaki öğrencilerin önemli bir kısmının da öğretmen olduklarında öğrencilerinin bireysel farklılıklarına ve kişisel alanlarına saygı duyacaklarını ifade etmeleri, ilahiyat eğitiminin öğrencilere uzlaşma anlayışı kazandırma noktasında etkili olduğu savını desteklemektedir.

\section{Sonuç}

Toplumsal birliğin tesis edilmesi ve ideal vatandaşların yetiştirilmesinde başat konumda olan olguların başında eğitim gelmektedir. Bu doğrultuda Türk eğitim sisteminde de sorumluluklarını bilen, yapıcı, yaratıcı, geniş bir dünya görüşüne sahip, hür ve bilimsel düşünen bireylerin yetiştirilmesi hedeflenir. Benzer amaçlara yüksek din öğretimi kurumlarında da yer verildiği için bu kurumların eleştirel düşünebilen, empati-iletişim kurabilen, uzlaşmaya açık bireyler yetiştirmesi ve bunu içeren bir

117 Bkz. Cemil Osmanoğlu, “Türkiye'de Yüksek Din Eğitimi ve Kurumsal Yabancılaşma: İlahiyat Fakültesi Örneği”, Erciyes Üniversitesi Sosyal Bilimler Enstitüsü Dergisi 31, sy 43 (2017): 210-16.

118 Detaylı bilgi için bkz. Osmanoğlu, 227-43.

119 Abdulvahap Taştan, Ali Kuşat, ve Celaleddin Çelik, "Üniversite Düzeyinde Din Öğretimi Alan Öğrencilerde Eğitim Sürecinde Oluşan Tutum ve Davranış Değişiklikleri (Erciyes Üniversitesi İlahiyat Fakültesi Örneği)", Erciyes Üniversitesi Sosyal Bilimler Enstitüsü Dergisi 1, sy 11 (2001): 188.

120 Aybiçe Tosun, "İlahiyat Fakültesi Öğrencilerinin XXI. Yüzyıl Öğrenen ve Öğreten Becerilerini Kullanım Düzeyleri”, Harran Üniversitesi İlahiyat Fakültesi Dergisi, sy 42 (2019): 299. 
programa sahip olması beklenir. Ancak bu kurumlara gelen öğrencilerin çoğunlukla programın genel amaçlarına bağlı bir eğitim talep ettiklerini söylemek güçtür.

Araştırmamıza katılan öğrenciler, ilahiyat lisans programıyla ilgili fikirlerini daha çok hadis, tefsir, kelam, İslam hukuku, İslam mezhepleri tarihi, İslam tarihi, din eğitimi, din psikolojisi, din sosyolojisi, dinler tarihi, felsefe ve formasyon dersleri üzerinden dile getirmişlerdir. Buradan hareketle öğrencilerin özellikle hadis, tefsir, kelam, İslam hukuku, İslam mezhepleri tarihi ve İslam tarihi derslerine yönelik kanaatlerinde farklılaşma olduğu dikkat çekerken; din eğitimi, din psikolojisi, din sosyolojisi, dinler tarihi, felsefe ve formasyon dersleriyle ilgili görüşlerinde ise böyle bir başkalaşmanın olmadığı fark edilmiştir.

Öğrenci fikirlerindeki farklılaşmanın üç temel nedenden kaynaklandığı söylenebilir. Bunlardan ilki hadis, tefsir, kelam gibi derslerin dinin temel kaynaklarına dayandığ 1 için alan dersleri olarak telakki edilmesi iken; din eğitimi, dinler tarihi, felsefe gibi derslerin destekleyici dersler olarak değerlendirilmesidir. Bu nedenle öğrenciler, ilk grupta yer alan derslerde kendi fikirlerinin dışında bir görüşle karşılaştıklarında bunu bir inanç meselesi olarak algılamakta ve bu durum ötekileştirme ve çatışmaya kapı aralamaktadır. Buna karşın ikinci gruptaki dersler, doğrudan dinî kaynakları referans almadığı için bu derslerdeki farklı fikirler, ötekileştirici ve çatışmaya sürükleyici bir etkiye sahip değildir. Ayrıca ilk gruptaki ders içeriklerinin hocaların kendi dinî görüşlerinin açığa çıkmasını kolaylaştırdığı için yorum çeşitliliğine neden olduğu; ikinci gruptaki ders içeriklerinin ise bu konuda hocalara daha az salahiyet tanıdığı için yorum yapmayı sınırlandırdığı söylenebilir. Bu sebeple ilk gruptaki derslerle ilgili öğrenci yorumlarında farklılaşma görülürken, ikinci gruptaki dersler için böyle bir farklılaşmayla karşılaşılmamaktadır.

Yorum farklılıklarının ikinci sebebi alandaki hoca sayısıyla doğru orantılıdır. Zira öğrencilerin çoğu, derslerle ilgili düşüncelerini hocalardan hareketle dile getirmiştir. Bu nedenle alan dersleri olarak zikredilen tefsir, hadis gibi derslere giren hoca sayısının, destekleyici ders kategorisine sokulan din psikolojisi, din sosyolojisi gibi derslere giren hoca sayısından fazla olması, yorum çeşitliliğine yol açmıştır. Buradan hareketle öğrencilerin alan derslerini yorumlarken hocaları göz önünde bulundurduğu ve düşüncelerinin çeşitlendiği görülmüştür.

Derslerle ilgili fikir farklılıklarının üçüncü nedeni ise öğrencilerin mevcut dinî görüşleridir. Çünkü öğrencilerin aldıkları ilahiyat eğitimini özellikle kendi dinî görüşüne yakın duruş sergileyen hocalar üzerinden değerlendirdikleri dikkat çekmiştir. Öğrencilerin bu konuda alan derslerinden hareket ettikleri ve kendilerini yakın hissettikleri hocaları empati ve uzlaşmaya katkı sağlayan, farklı görüşlere sahip hocaları ise ötekileştirme ve çatışmaya yol açan kişiler olarak kodladıkları tespit edilmiştir. 
Öğrencilerin derslerle ilgili yorum farklılıkları; öteki, çatışma, empati-iletişim ve uzlaşma temalarına dair fikirlerinde de kendini göstermiştir. Öğrenciler öteki ve çatışma konularında arkadaşlarında birtakım eksiklikler olduğunu ifade etmelerine rağmen, empati ve uzlaşma hususlarında olumlu gelişme kat ettiklerinin de altını çizmişlerdir. İlk bakışta çelişki gibi algılanabilecek bu durum, aslında eğitimin bireyde meydana getirdiği değişimin somut bir örneğini temsil etmektedir. Nitekim öğrencilerin çoğunun ilahiyat eğitimi süresince herkesin bu konularda az ya da çok olumlu anlamda kendini geliştirdiğini ifade etmesi, bu tespiti desteklemektedir. Şüphesiz bu gelişme, yaşanan ötekileştirmelerin ve çatışmaların ortadan kalkmasa dahi hafiflemesine olanak tanımaktadır.

Tüm bunlardan hareketle öğrencilerin zihinlerinde öteki, çatışma, empati ve uzlaşma kavramlarının tam karşılığının olmadığı ve bu temalara ilişkin değerlendirme yaparken parçacı bir yaklaşım benimsedikleri söylenebilir. Bir diğer ifadeyle öğrenciler, tekil örneklerden hareket ederek, genel çıkarımlarda bulunmaktadırlar. Bunun bir yansıması olarak açığa çıkan öğrenci görüşleri zaman zaman kendi içinde bazı çelişkiler barındırabilmektedir. En nihayetinde aldıkları ilahiyat eğitimi hakkında öğrencilerde uzlaşma, çatışma, empati ve iletişim açısından bütüncül bir bakış açısı gelişmemektedir.

Hakem Değerlendirmesi: Dış bağımsız.

Çıkar Çatışması: Yazarlar çıkar çatışması bildirmemiştir.

Finansal Destek: Yazarlar bu çalışma için finansal destek almadığını beyan etmiştir.

Peer-review: Externally peer-reviewed.

Conflict of Interest: The authors have no conflict of interest to declare.

Grant Support: The authors declared that this study has received no grant support.

\section{Kaynakça/References}

Akyol, Pelin. "Farklı Fakültelerdeki Öğrencilerin İletişim Becerilerinin Karşılaştırılması". Spor Ĕ̆itim Dergisi 3, sy 3 (2019): 71-77.

Altan, Yakup. “Örgütsel Çatışma ve Etkileri”. Dumlupınar Üniversitesi Sosyal Bilimler Dergisi, sy 27 (2015).

Altaş, Nurullah, ve Celal Büyük. "Öğretmen Yetiştiren Bir Kurum Olarak İlahiyat Eğitiminin Genel Hedefleri Altında Din Eğitimi ve Din Felsefesi Eğitimi İlişkisi (Din Eğitimi ve Din Felsefesi İlişkisi Özel Amaçlara Nasıl Yansımalı?)". Din ve Felsefe Araştırmaları 1, sy 2 (2018): 115-33.

Apak, Âdem. Ana Hatlarıla İslam Eğitim Tarihi 2 (Hulefâ-i Râşidîn Dönemi). İstanbul: Ensar Neşriyat, 2013.

Apaydın, Halil. “Empati”. İçinde Din Psikolojisi Terimler Sözlüğü, 92-93. İstanbul: Bilimkent Yayınları, 2016. 
Arıc1, İsmail, ve Yasemin Nakşiye Angın. "İlahiyat Fakültesi Öğrencilerinin İletişim Beceri Düzeyleri”. Amasya Üniversitesi İlahiyat Fakültesi Dergisi, sy 8 (2017): 199-219.

Aronson, Elliot, Timothy D. Wilson, ve Robin M. Akert. Sosyal Psikoloji. Çeviren Okhan Gündüz. İstanbul: Kaknüs Yayınları, 2012.

Aşıkoğlu, Nevzat Yaşar. "İlahiyat Fakültelerinin Eğitim Öğretime Katkıları ve Kaliteye Yolculuk”. Cumhuriyet Üniversitesi Illahiyat Fakültesi Dergisi 9, sy 1 (2005): 1-10.

—. "Yükseköğretimde Din Eğitimi ve Öğretimi”. İçinde Din Eğitimi, editör Recai Doğan ve Remziye Ege, 183-99. Ankara: Grafiker Yayınları, 2016.

Aydın, Ali Rıza. “Öğretmen-Öğrenci İlişkilerinde Empati ve Öğretmenlerin Rol Modelliği Üzerine”. Dinbilimleri Akademik Araştırma Dergisi 9, sy 4 (2009): 75-84.

Aydın, Mahmut. "Paradigmanın Yeni Adı: Dinsel Çoğulculuk”. İçinde Hıristiyan, Yahudi ve Müslüman Perspektifinden Dinsel Çoğulculukve Mutlaklık İddiaları, editör Mahmut Aydın, 15-49. Ankara: Ankara Okulu Yayınları, 2005.

Aydın, Muhammet Şevki. Açık Toplumda Din Eğitimi Yeni Paradigma İhtiyacı. Ankara: Nobel Akademik Yayınc1lık, 2018.

—. Din Ë̆itimi Bilimi. Kayseri: Kimlik Yayınevi, 2017.

_. "İlahiyat Lisans Programının Amaç Sorunu”, 19-25. Isparta: SDÜ İlahiyat Fakültesi Yayınları, 2004.

. “İslam Eğitim Geleneğinde Öğretmenlik”. Erciyes Üniversitesi İlahiyat Fakültesi Dergisi, sy 11 (2001): 59-74.

Aydın, Muhammet Şevki, ve Cemil Osmanoğlu. Kültürlerarası Din Eğitimi. Ankara: Nobel Akademik Yayıncılık, 2015.

Aydın, Mustafa. Sistematik Din Sosyolojisi. İstanbul: Aç1lım Kitap, 2014.

Aydınalp, Halil. "Sosyal Çatışma ve Din”. Uludağ Üniversitesi İlahiyat Fakültesi Dergisi 19, sy 2 (2010): 187-215.

Bakırcıŏlu, Rasim. “Uyum II”. İçinde Ansiklopedik Eğitim ve Psikoloji Sözlüğ̈̈, 945-46. Ankara: Anı Yayınc1lık, 2012.

Başkurt, İrfan. "Eğitimde Çocuk ve ‘Öteki’nin Kimliği Problemi”. İstanbul Üniversitesi İlahiyat Fakültesi Dergisi, sy 5 (2002): 113-41.

Batar, Yusuf. Empatik Din Eğitimi. İstanbul: Elips Kitap, 2011.

Bayrakdar, Nazım. “İslami İlimler Fakültesi Öğrencilerine Göre Derslere Yönelik Olumlu Tutum Geliştirmelerine Katkı Sağlayan Öğretim Elemanı Davranışları”. Insan ve Toplum Bilimleri Araştırmaları Dergisi 5, sy 8 (2016): 3033-53.

Bayraktar, Mehmet Faruk. İslam Eğitiminde Öğretmen-Öğrenci Münasebetleri. İstanbul: Marmara Üniversitesi İlahiyat Fakültesi Vakfi Yayınları, 2018.

Bilecik, Sümeyra. "İlahiyat Fakültesi Öğrencilerinin Dinde Yenilikçiliğe Bakış Açıları ve Eleştirel Düşünme Eğilimi İlişkisi (NEÜ İlahiyat Fakültesi Örneği)”. Marife Dini Araştırmalar Dergisi 19, sy 2 (2019): 291-320.

Bilgin, Beyza. “İslam’da Ötekine Bakış”. Ankara Üniversitesi İlahiyat Fakültesi Dergisi 42, sy 1 (2001): 11-40.

Bilgin, Nuri. “Çatışma”. İçinde Sosyal Psikoloji Sözlüğü Kavramlar, Yaklaşımlar, 73. İstanbul: Bağlam Yayıncılık, 2016. 

2006.

Boz, Abdulvehap. "Öğretim Elemanlarının İstenmeyen Davranışları İle Öğrenci Yabancılaşması Arasındaki İlişki”. Pamukkale Üniversitesi Eğitim Fakültesi Dergisi, 2020, 1-26.

Bulut, Ramazan. "İslami İlimler Fakültesi Öğrencilerinin Dini Gruplar Hakkındaki Görüşleri Üzerine Bir Araştırma". Dinbilimleri Akademik Araştırma Dergisi 20, sy 1 (2020): 359-95.

Buyrukçu, Ramazan. "İlahiyat Fakültelerinin Yeniden Yapılandırılması Problemi”, 509-20. Isparta: SDÜ İlahiyat Fakültesi Yayınları, 2004.

Büyükkara, Mehmet Ali. "Mezhepsel Uzlaşma ve Barış: Modern ve Postmodern Yaklaşımlar”. Divan Disiplinlerarası Çalışmalar Dergisi 18, sy 35 (2013): 109-38.

Büyüköztürk, Şener, Ebru Kılıç Çakmak, Özcan Ercan Akgün, Şirin Karadeniz, ve Funda Demirel. Bilimsel Araştırma Yöntemleri. Ankara: Pegem Akademi, 2017.

Cevizci, Ahmet. "Empati”. İçinde Felsefe Sözlüğ̈̈, 351-52. İstanbul: Paradigma Yayınları, 2002.

Creswell, John W. Nitel Araştırma Yöntemleri Beş Yaklaşıma Göre Nitel Araştırma ve Araştırma Deseni. Çeviren Mesut Bütün ve Selçuk Beşir Demir. Ankara: Siyasal Kitabevi, 2018.

Cüceloğlu, Doğan. İnsan ve Davranışı. İstanbul: Remzi Kitabevi, 2017.

Çakmak, Veysel, ve Ercan Aktan. "Öğretmen Öğrenci İletişiminin Çeşitli Değişkenlere Göre İncelenmesi”. Elektronik Sosyal Bilimler Dergisi 15, sy 56 (2016): 83-97.

Çalışkan, İsmail. "Dini Bir Tutum Olarak Ötekine Yaklaşımın Kur’anî Temelleri”. Cumhuriyet Üniversitesi İlahiyat Fakültesi Dergisi 11, sy 1 (2007): 7-28.

Çinemre, Semra. "İlahiyat Fakültesi Son Sınıf Öğrencilerinin İlahiyat Fakültesi Programına İlişkin Algılarının Metafor Analizi Yoluyla İncelenmesi”. Ilahiyat Tetkikleri Dergisi, sy 52 (2019): 265-86.

Doğan, Recai. "İlahiyat Fakültelerinin Eğitim Anlayışı Nasıl Olmalıdır?”, 351-70. İstanbul: Ensar Neşriyat, 2015.

Döğüşgen, Mehmet Murat. "Çatışma”. İçinde Psikoloji Psikiyatri Sözlüğü, 58. İstanbul: Emre Yayınları, 2005.

—_. "Empati”. İçinde Psikoloji Psikiyatri Sözlü̆̆̈̈, 79. İstanbul: Emre Yayınları, 2005.

Dökmen, Üstün. Evrenle Uyumlaşma Sürecinde Varolmak, Gelişmek, Uzlaşmak. İstanbul: Remzi Kitabevi, 2017.

—. Iletişim Çatışmaları ve Empati. İstanbul: Remzi Kitabevi, 2018.

Ekiz, Durmuş. Bilimsel Araştırma Yöntemleri. Ankara: Anı Yayıncılık, 2017.

Eren, Muhammet Emin. “İslam Toplumunda Ayrıştırıcı/Ötekileştirici Söylemin Oluşumunda İftirak (73 Fırka) Hadisinin Rolü”. İçinde Kur'an ve Toplumsal Bütünleşme (Mezhepler ve Dini Gruplar Arası İlişkiler), editör Hayati Hökelekli ve Vejdi Bilgin, 19-34. Bursa: Bursa Büyükşehir Belediyesi Yayınları, 2015.

Ergin, Akif, ve Aynur Geçer. “Öğrenci Algılarına Göre Öğretim Elemanlarının İletişim Biçimleri”. Ankara Üniversitesi Eğitim Bilimleri Fakültesi Dergisi 41, sy 2 (2008): 1-28.

Erpay, İlyas. "Öğrencilerin İlahiyat Fakültesine Yönelik Görüşleri”. Amasya İlahiyat Dergisi, sy 13 (2019): 423-73.

Ersanlı, Kurtman. “Ortaöğretimde Öğretmen-Öğrenci İlişkilerinin Dayandığı Temeller”. Ondokuz Mayıs Üniversitesi Eğitim Fakültesi Dergisi 4, sy 1 (2014): 40-44. 
Ev, Halit. "Yükseköğretimde Din Eğitimi”. İçinde Din Eğitimi, editör Mustafa Köylü ve Nurullah Altaş, 268-306. İstanbul: Ensar Neşriyat, 2016.

Furat, Ayşe Zişan. İslam Toplumunda Kimlik Oluşumu ve Din Eğitimi. Konya: Yediveren Kitap, 2013.

Furseth, Inger, ve Pal Repstad. Din Sosyolojisine Giriş Klasik ve Çăgdaş Kuramlar. Çeviren İhsan Çapçığlu ve Halil Aydınalp. Ankara: Birleşik Yayınevi, 2011.

Güçlü, Abdülbaki, Erkan Uzun, Serkan Uzun, ve Ümit Hüsrev Yolsal. “Öteki”. İçinde Felsefe Sözlüğü, 1101-4. Ankara: Bilim ve Sanat Yayınları, 2002.

Güloval1, M. Çetin, ve Ayşenur Odabaş. "Çatışma”. İçinde Türkçe Bilim Terimleri Sözlügü Sosyal Bilimler, 233-34. Ankara: Türkiye Sosyal Bilimler Akademisi, 2011.

Gümüş, Nebi. “Osmanlı'da Birlikte Yaşama Tecrübesi: Ermeniler Örneği”. Milel ve Nihal: İnanç, Kültür ve Mitoloji Araştırmaları Dergisi 6, sy 2 (2009): 165-98.

Gündoğdu, Hakan. “Çok Kültürlü Bir Toplumda Ötekiyle Yaşamak ve Hoşgörü”. EKEV Akademi Dergisi, sy 37 (2008): 73-86.

Güneş, Abdurrahman. “Toplumsal Bir Zorunluluk: Bir Arada Yaşamak”. Fırat Üniversitesi İlahiyat Fakültesi Dergisi 10, sy 2 (2005): 89-103.

Gürün, O. A. “Çatışma”. İçinde Psikoloji Sözlüğü, 29. İstanbul: İnkılap Kitabevi, t.y.

İnan, Ahmet. “Kur'anda Uzlaşmanın Anahtar Kavramları”. İçinde Kur'an 'nın Farklı İnanç Mensuplarına Yaklaşımı Sempozyumu, 148-61. Konya: Konya İlahiyat Derneği Yayınları, 2007.

Kağıtçıbaşı, Çiğdem, ve Zeynep Cemalcılar. Dünden Bugüne İnsan ve Insanlar Sosyal Psikolojiye Giriş. İstanbul: Evrim Yayınevi, 2018.

Kasapoğlu, Abdurrahman. "Empati ve Sempati Olgusuna Vurgu Yapan Bazı Ayetler". Bilimname, sy 1 (2006): 33-61.

Kaya, Mehmet Tamer, Barış Çiftçi, ve Abdullah Gökdemir. "Sosyal Bilgiler Öğretmen Adaylarının İletişim Becerilerinin Çeşitli Değişkenler Açısından İncelenmesi”. International Primary Education Research Journal 3, sy 1 (2019): 31-37.

Koç, Ahmet. Din Eğitiminde Etkili İletişim. İstanbul: Rağbet Yayınları, 2016.

"İlâhiyat Fakültesi (İlâhiyat Lisans Programı) Öğrencilerinin Sorunları ve Beklentileri”. Marmara Üniversitesi İlahiyat Fakültesi Dergisi 25, sy 2 (2003): 25-64.

Koçak, Zahide Kübra, ve Mehmet Ali Aktaş. "Çatışma ve Çatışma Yönetimi Kavramlarına Güncel Bir Bakış”. Niğde Ömer Halisdemir Üniversitesi Sosyal Bilimler Enstitüsü Dergisi 1, sy 2 (2019): 130-37.

Köylü, Mustafa. "Psiko-Sosyal Açıdan Dini İletişim”. Doktora Tezi, Ondokuz Mayıs Üniversitesi, Sosyal Bilimler Enstitüsü, 2002.

Köylü, Mustafa, ve Ahmet Koç, ed. Klasik Íslam Eğitimcileri. İstanbul: Rağbet Yayınları, 2016.

Lakitsch, Maximilian. "Islam in the Syrian War: Spotting the Various Dimensions of Religion in Conflict”. Religions 9, sy 8 (2018): 1-17.

Margalit, Avishai. Uzlaşma ve Kokuşmuş Uzlaşmalar. Çeviren Nedim Çatlı. İstanbul: İthaki Yayınları, 2013.

Masaloğulları, Güncel, ve Muhammet Koçakgöl. “Çatışma”. İçinde Psikoloji Sözlüğü, 38. Ankara: Nobel Akademik Yayıncılık, 2011.

Nazıroğlu, Bayramali. Derdimiz İlahiyat -Akademisyenlerinin Gözünden İçe Kritik Baklş-. İstanbul: Okur Akademi, 2020. 
İslam Ĕ̆itim Geleneğinde Öğretmenlik. Ankara: Sarkaç Yayınları, 2011.

Osmanoğlu, Cemil. “Türkiye'de Yüksek Din Eğitimi ve Kurumsal Yabancılaşma: İlahiyat Fakültesi Örneği”. Erciyes Üniversitesi Sosyal Bilimler Enstitüsü Dergisi 31, sy 43 (2017): 197-262.

Osmanoğlu, Cemil, ve Mehmet Korkmaz. "Öğrencilerine Göre İdeal İlahiyat Fakültesi Öğrencisinin Nitelikleri ve Bunun İlahiyat Eğitimiyle İlişkisi”. Değerler Eğitimi Dergisi 16, sy 36 (2018): 119-78.

Öncül, Remzi. “Çatışma”. İçinde Eğitim ve Eğitim Bilimleri Sözlüğü, 229-30. İstanbul: Milli Eğitim Bakanlığı Yayınları, 2000.

__. "Uzlaşma”. İçinde Eğitim ve Eğitim Bilimleri Sözlüğü, 118. İstanbul: Milli Eğitim Bakanlığı Yayınları, 2000.

Öz, Mustafa. Başlangıçtan Günümüze İslâm Mezhepleri Tarihi. İstanbul: Ensar Neşriyat, 2016.

Özdeş, Talip. “Çatışma veya Uzlaşma 21. Yüzyıla Girerken Çoğulculuğa Kur'an Açısından Bir Bakış”. Cumhuriyet Üniversitesi Illahiyat Fakültesi Dergisi, sy 4 (2000): 179-92.

Öztürk, Mustafa. “'İlahiyat'ın Ad1 ve Amaçları”. İçinde Bugünün İlahiyatı Nasıl Olmalıdır? Sorunlar ve Çözümleri, 29-59. İstanbul: Ensar Neşriyat, 2015.

Patton, Michael Quinn. Nitel Araştırma ve Değerlendirme Yöntemleri. Çeviren Mesut Bütün ve Selçuk Beşir Demir. Ankara: Pegem Akademi, 2018.

Recep Tayyip Erdoğan Üniversitesi İlahiyat Fakültesi. “... İlahiyat Fakültesi Lisans Programı”. Erişim 25 Kasım 2018. http://bologna.erdogan.edu.tr/organizasyonInfo.php?kultur=trTR\&mod=1\&program=237\&yil=2019.

Rogers, Carl R. "Empatik Olmak, Değeri Anlaşılmamış Bir Varoluş Şeklidir". Çeviren Füsun Akkoyun. Ankara Üniversitesi Ĕ̆itim Bilimleri Fakültesi Dergisi 16, sy 1 (1983): 103-24.

Sarıçam, İbrahim. Hz. Muhammed ve Evrensel Mesajı. Ankara: Diyanet İşleri Başkanlığı Yayınları, 2011.

Sinanoğlu, A. Faruk. "Evrensel Düzeyde Uzlaş1 ve Hoşgörü Kültürünün İmkânı”. Hikmet Yurdu 5, sy 9 (2012): 25-35.

Sülün, Murat. "Sevgi ve Nefret Bağlamında Kuran'a Göre Öteki: -Kimi Sevip Kimi Sevmeyeceğiz?-". İçinde İslam'da Sevgi Temelinde Beşeri Münasebetler-Illmi Toplantı, 317-35, 2010.

Tarhan, Nevzat. Toplum Psikolojisi ve Empati Sosyal Şizofreniden Toplumsal Empatiye. İstanbul: Timaş Yayınları, 2017.

Taşkıran, Ayşe. "İlahiyat Fakültesi Müfredatında Felsefe ve Din Bilimleri Bölümü Derslerinin Yeri ve Fonksiyonlarına Dair Bir Araştırma (İlahiyat Fakültesi Öğrencileri Örneği)”. Kahramanmaraş Sütçü Imam Üniversitesi İlahiyat Fakültesi Dergisi 11, sy 22 (2013): 238-66.

Taştan, Abdulvahap, Ali Kuşat, ve Celaleddin Çelik. "Üniversite Düzeyinde Din Öğretimi Alan Öğrencilerde Eğitim Sürecinde Oluşan Tutum ve Davranış Değişiklikleri (Erciyes Üniversitesi İlahiyat Fakültesi Örneği)". Erciyes Üniversitesi Sosyal Bilimler Enstitüsü Dergisi 1, sy 11 (2001): 169-92.

TDK. “Uzlaşma”. İçinde Türkçe Sözlük, 2437. Ankara: Türk Dil Kurumu Yayınları, 2011.

Tetik, Hayati. "Din Hizmetlerinde İletişim Becerileri ve Empati”. EKEV Akademi Dergisi, sy 41 (2009).

Tokat, Bülent. “Örgütlerde Çatışma ve Çatışmanın Yönetimi”. Dumlupınar Üniversitesi Sosyal Bilimler Dergisi, sy 1 (1999): 23-40.

Toktaş, Fatih, ve H. Yusuf Acuner. “İlahiyat Fakültelerinde Felsefe Dersleri Ondokuz Mayıs Üniversitesi İlahiyat Fakültesi Örneği”. Ondokuz Mayıs Üniversitesi Illahiyat Fakültesi Dergisi, sy 17 (2004): 159-75. 
Topaloğlu, Bekir. Kelam İlmine Giriş. İstanbul: Damla Yayınevi, 2014.

Tosun, Aybiçe. "İlahiyat Fakültesi Öğrencilerinin XXI. Yüzyıl Öğrenen ve Öğreten Becerilerini Kullanım Düzeyleri”. Harran Üniversitesi Illahiyat Fakültesi Dergisi, sy 42 (2019): 287-309.

Turan, İbrahim. “Türkiye'de İlahiyat Eğitimi: İstihdam Alanı-Program İlişkisi Üzerine Bir İlişki”. İstanbul Üniversitesi Illahiyat Fakültesi Dergisi, sy 37 (2017): 59-77.

Türer, Celal. "Uzlaşma/nın Felsefesi”. Ombudsman Akademik, sy 4 (2016): 171-88.

Uçar, Recep. "İlahiyat Fakültesi Öğrencilerinin Profili, Akademik Eğilimleri ve Aldıkları Eğitime İlişkin Memnuniyet Algıları (İnönü Üniversitesi Örneği)”. İnönü Üniversitesi İlahiyat Fakültesi Dergisi 8, sy 2 (2017): 105-78.

Yaka, Aydın. Sosyoloji Yazıları Çatı̧̧ma Kültüründen Uzlaşma Kültürüne. İstanbul: Gündoğan Yayınları, 2018.

Yapıcı, Asım, ve Kadir Albayrak. “'Öteki’ni Algılama Bağlamında Dinî Gruplar Arası İlişkiler”. Dini Araştırmalar 5, sy 14 (2002): 35-59.

Yavuz, Şevket. “İslâm'ın Ötekileştirmeye Meydan Okuması veya 'Ontolojik Öteki'den 'Vasıfsal Öteki’ne İntikalin Macerası”. Marife, sy 3 (2006): 135-56.

_ . “'Öteki' ile 'Beriki’ Arasındaki Salınımda Dinlerde Birlikte ve Beraber Yaşamanın Teolojik ve Pratik İmkanı”. Milel ve Nihal: İnanç, Kültür ve Mitoloji Araştırmaları Dergisi 6, sy 2 (2009): $31-50$.

Yazıbaşı, Muhammed Ali. "Yükseköğretimde Din Eğitimi”. İçinde Din Eğitimi, editör Hasan Dam, 152-68. İstanbul: Lisans Yayınc1l1k, 2018.

Yeğin, Hüseyin İbrahim. “İlahiyat Fakültesi Öğrencilerinin Bireysel Yenilikçilik Düzeyleri”. $A \dot{I} B \ddot{U}$ Sosyal Bilimler Enstitüsü Dergisi 17, sy 4 (2017): 239-62.

Yeşilyurt, Temel. “'Ben'in 'Öteki'leşmesi ya da Söylemin Ayrılığı Çatışma Teolojisinden Uzlaşma Teolojisine”. Islamiyat 7, sy 3 (2004): 149-62.

Yıldırım, Ali, ve Hasan Şimşek. Sosyal Bilimlerde Nitel Araştırma Yöntemleri. Ankara: Seçkin Yayıncılık, 2016.

Yıldız, Kaya. “Üniversitelerde Çatışma ve Çatışma Yöntemi”. Abant İzzet Baysal Üniversitesi Eğitim Fakültesi Dergisi 3, sy 1 (2016): 107-24.

Y1lmaz, Hüseyin. Din Eğitimi ve Sosyal Barış. İstanbul: İnsan Yayınları, 2003.

Yılmaz, Mehmet Nuri. “İslâm ve Dinler Arası Birlikte Yaşama”. Diyanet İlmi Dergi 34, sy 2 (1998): 3-20. 